\title{
Deception in Undercover Investigations: Conduct-Based vs. Status-Based Ethical Analysis
}

\author{
Barry R. Temkin ${ }^{\dagger}$
}

\section{INTRODUCTION}

The ABA Model Rules of Professional Conduct (Model Rules), by their terms, bar lawyers from engaging in conduct involving "dishonesty, fraud, deceit or misrepresentation." yers from circumventing the rules by proxy. Yet, lawyers throughout the United States supervise undercover investigators who misrepresent their identities in order to garner admissions or other evidence from unsuspecting would-be adversaries. These adversaries believe that they are dealing with members of the general public, not investigators who plan to help arrest or sue them.

There has been some debate about whether lawyer involvement in undercover deception is or should be barred by the literal language of Model Rule 8.4, which proscribes deceit and dishonesty. ${ }^{2}$ There is a tension between the language of the Model Rules and the actual practice in most jurisdictions, in which government lawyers, especially prosecutors, regularly supervise undercover investigations. Lawyers who supervise undercover investigations employ deception, albeit, generally speaking, indirectly through investigators. A federal prosecutor supervising a criminal terrorism investigation approves of the use of a false name and identity by the undercover investigator. A civil rights attorney preparing

\footnotetext{
${ }^{\dagger}$ Barry R. Temkin is an adjunct professor at New York Law School and Chair of the New York County Lawyers Association Professional Ethics Committee. The views expressed in this article are those of the author alone, as are the errors. The author thanks Elizabeth Chambliss, Carol A. Buckler, and James B. Kobak, Jr., for generously reviewing and commenting on an earlier draft of this article. The author further acknowledges the assistance of Johara P. Tucker, New York Law School class of 2008, as a research assistant. The author welcomes comments at Barry.Temkin@gmail. com.

1. Model Rules OF Prof'L CONDUCt R. 8.4(c) (2008) [hereinafter MODEL Rules].

2. Id.
} 
to bring a civil housing discrimination case assists an undercover investigator in assuming a false name and identity that is used to deceive the target of the investigation, who presumably would not make damaging admissions to a fully-disclosed agent of a civil rights organization.

A few recent examples help to illustrate the need for more guidance in attorney-supervised investigations. The Hewlett-Packard scandal directed public attention not only on pretexting, ${ }^{3}$ but on the whole panoply of undercover investigations, as well as attorneys' responsibility for the techniques utilized by investigators under the attorneys' supervision. ${ }^{4}$ In the course of investigating corporate leaks to the press from a member of the Hewlett-Packard board of directors, HP in-house counsel Kevin Hunsaker approved the use of pretexting by investigators, who then obtained confidential phone records not only from the suspected board members, but also from nine journalists and their relatives. ${ }^{5}$ The investigators posed as the target board members in order to illegally obtain confidential telephone records. ${ }^{6}$

Another illustration of attorney supervision of undercover investigations arises from a recent Wisconsin case. ${ }^{7}$ A February 2008 decision by a Wisconsin referee exonerated criminal defense lawyer Stephen Hurley, whose investigator used a ruse to trick a teenage boy into exchanging his computer for a new laptop. ${ }^{8}$ Hurley represented a suspect accused of child molestation. ${ }^{9}$ His investigator, using a false pretense, tricked the complaining witness into surrendering his computer, which contained evidence of pornography obtained from other sources. ${ }^{10}$ The Wisconsin Office of Lawyer Regulation filed an ethics complaint against Hurley alleging that the investigation involved fraud, deception and dis-

3. "Pretexting" has been defined as "a practice where an individual lies about her identity in order to obtain confidential or privileged information that she is not entitled to." Patrick M. Arenz, The Truth Behind Pretexting: In-House Investigations and Professional Responsibility Concerns, Apr. 2007, http://www.rkmc.com/The-Truth-Behind-Pretexting-In-house-Investigations-and-Profess ional-Responsibility-Concerns.htm.

4. Id.

5. Arenz, supra note 3; James B. Stewart, The Kona Files, How an Obsession with Leaks Brought Scandal to Hewlett-Packard, THE NEW YORKER, Feb. 19 \& 26, 2007, at 152, 159-60; Damon Darlin, Journalists Intend to Sue Hewlett-Packard Over Surveillance, N.Y. TIMES, May 7, 2007 , at $\mathrm{C} 4$.

6. See Stanley S. Arkin \& Sean R. O'Brien, Effective Use of Private Investigators by Attorneys, N.Y.L.J., Dec. 26, 2007, at 3.

7. See Political Capital, http://political-capital.blogspot.com/2008/02/professional-complaintagainst-madison.html (Feb. 6, 2008, 12:09 EST).

8. See id.; Supreme Court Referee: Hurley Didn't Break Ethics Rules, LA CrossE TRIBUNE, Feb. 6, 2008, available at http://www.lacrossetribune.com/articles/2008/02/06/wi/06wis06.txt [hereinafter Supreme Court Referee].

9. Supreme Court Referee, supra note 8.

10. Id. 
honesty. ${ }^{11}$ But the special referee dismissed the charges, noting that the ethics rule was vague, ill-defined, and in any event trumped by the lawyer's duty to his client. ${ }^{12}$ Moreover, it was the investigator, not the lawyer, who engaged in deception. The court-appointed referee, noting that "[a] man's liberty was at stake," stated that the lawyer's conduct, while deceitful, was not unethical. ${ }^{13}$

Some courts and commentators have opined that deception is simply never permitted by attorneys under any circumstances. ${ }^{14}$ In contrast, other jurisdictions have amended their ethics rules to permit lawyers to supervise undercover investigations, but only government lawyers, and only in criminal prosecutions. ${ }^{15}$ A few authorities have held that deceptive undercover investigative techniques are permitted to combat discrimination and to enforce trademarks. ${ }^{16}$ This Article argues that it is inherently subjective and value-laden to posit that one substantive subject area of the law justifies indirect deception, while another does not. This Article recommends that ethics rules should focus on the conduct of the attorney, rather than on the subject matter of the specific case or on the status of the attorney's client.

For the sake of this Article, attorney supervision of undercover investigations will be analyzed along two conceptual axes. Axis 1 considers the nature of the substantive subject matter of the underlying claim (e.g., trademark or criminal) and the status of the attorney (public vs. private or plaintiff vs. defense). This approach will be called the "statusbased axis." 17 Axis 2 focuses on the conduct of the attorney and investigator, as the attorney's agent. The Axis 2 factors include the following: the extent of the misrepresentation; whether the deceit is direct or indirect; the existence of other, alternative methods of obtaining the same evidence; and whether the questioned conduct violates another ethics rule or principle of substantive law. Such rules include the "no-contact rule" of Model Rule 4.2 and the various laws and regulations regarding

11. Id.

12.1d.

13. See id.

14. See, e.g., In re Pautler, 47 P.3d 1175, 1180 (Colo. 2002) (en banc) ("[P]rosecutors cannot involve themselves in deception, even with selfless motives ...."); Michael Bonsignore, Rules Exist for a Reason: A Commentary on Lawyers Hiring Investigators to Partake in Deceptive Tactics, 21 GEO. J. LEGAL ETHICS 655, 662 (2008) ("Allowing either direct deceptive tactics, or employing an investigator to engage in such tactics, when the information is attainable within the system is incongruent with the moral basis of the adversarial system.").

15. See infra Part V.

16. See, e.g., Apple Corps Ltd. v. Int'l Collectors Soc'y, 15 F. Supp. 2d 456, 475 (D.N.J. 1998).

17. Alternatively, Axis 1 could be labeled the "subject-matter axis" because it is dependent on the substantive nature of the client's underlying claim. 
pretexting and breach of privacy, some of which were adopted in the wake of the 2006 Hewlett-Packard corporate scandal. ${ }^{18}$

The development of status-based exceptions to ABA Model Rule 8.4-exceptions based on the status of the attorney or the client's underlying substantive claim-raises interesting and troubling issues. Where will the line be drawn? Should attorney-supervised undercover investigations be limited to certain substantive areas of practice? If a prosecutor can employ an undercover investigator to deceive others in a death penalty case, perhaps the defense attorney in the same case should be permitted to instruct an investigator to take the same liberties with the truth. Arguably, preventing the conviction of an innocent defendant is as worthy a goal as securing the conviction of a guilty suspect. The same types of questions can be posed for attorneys defending intellectual property and civil rights cases for whom there has been little, if any, authority justifying deceptive investigations. By the same token, we can compare other social values, such as protecting the environment, preventing workplace accidents, or even saving human life, with the values that justify deception in trademark and discrimination cases. If attorneys can indirectly deceive in order to protect a property right, then why not permit lying to protect our environment or to rectify a less lofty civil wrong?

Part II of this Article briefly sketches the overall ethical framework under the ABA Model Rules and the ABA Model Code of Professional Responsibility, including the proscription on deceit and misrepresentation in Model Rule 8.4 and the ban on attorney contact with represented adverse parties in Model Rule 4.2. Part III describes the jurisdictions that have declined to create status-based exceptions to Model Rule 8.4, and the nationwide uproar created when the Oregon Supreme Court initially refused to permit undercover investigations involving any deception-including investigations by law enforcement personnel. That Part will also trace the subsequent adoption of a new rule in Oregon, which now permits all attorneys, regardless of public or private status, to supervise investigations involving deceit, provided that there is evidence of underlying unlawful conduct. Part IV describes the development of status-based exceptions, which have authorized government lawyers to supervise undercover criminal investigations and have permitted plaintiffs' lawyers to dispatch testers in intellectual property and civil rights cases.

Part V explains efforts by various state bars to reconcile the conflict between the literal language of the Model Rules and the common practice, in which lawyers indeed have participated in undercover investigations involving trickery and deception. Part VI argues that status-based 
distinctions have outlived their purpose and should be reconsidered. Finally, Part VII suggests a number of conduct-based factors that should be used to analyze the conduct of all lawyers, regardless of an attorney's status or nature of the client's substantive legal claim.

\section{ABA MODEL RULES FRAMEWORK}

\section{A. Deceit and Dishonesty}

Our analysis begins with the ABA Model Rules of Professional Conduct, which outline lawyers' responsibilities to their clients, to tribunals, and to others. The Model Rules proscribe deception in Rule 8.4, which provides in pertinent part as follows:

It is professional misconduct for a lawyer to:

(a) violate or attempt to violate the Rules of Professional Conduct, knowingly assist or induce another to do so, or do so through the acts of another;

(b) commit a criminal act that reflects adversely on the lawyer's honesty, trustworthiness or fitness as a lawyer in other respects;

(c) engage in conduct involving dishonesty, fraud, deceit or misrepresentation .... ${ }^{19}$

The comments to Rule 8.4 add a gloss on the types of illegal conduct that would constitute professional misconduct: "Many kinds of illegal conduct reflect adversely on fitness to practice law," generally crimes of what used to be called "moral turpitude." 20 While a lawyer is personally answerable to the entire criminal law, "a lawyer should be professionally answerable only for offenses that indicate lack of those characteristics relevant to law practice." ${ }^{21}$ This comment has been seized upon in an influential article by David Isbell and Lucantonio Salvi, who argue that its language modifies Rule 8.4(c), which should accordingly be read to prohibit only that dishonesty, fraud, deceit, or misrepresentation that adversely affects a lawyer's fitness to practice law. ${ }^{22}$ According to these

19. MODEL RULES R. 8.4 .

20. Id. cmt. 2.

21. Id.

22. David Isbell \& Lucantonio Salvi, Ethical Responsibility of Lawyers for Deception by Undercover Investigators and Discrimination Testers: An Analysis of the Provisions Prohibiting Misrepresentation Under the Model Rules of Professional Conduct, 8 GEO. J. LEGAL ETHICS 791 (1995). 
authors, the proscription of deceit in Rule 8.4(c) "should apply only to grave misconduct that would not only be generally reproved if committed by anyone, whether lawyer or nonlawyer, but would be considered of such gravity as to raise questions as to a person's fitness to be a lawyer. ${ }^{23}$ Because civil rights testing is necessary to remedy the evil of discrimination, it is socially desirable, and the use of testers is not the kind of deception forbidden by Rule 8.4. ${ }^{24}$

While Isbell and Salvi's article has had some traction, and has even inspired an amendment in state ethics codes, ${ }^{25}$ their approach has had its critics. One commentator noted that Comment [2] to Rule 8.4, judging from its context, is intended to interpret Rule 8.4 (b) only, by specifying the type of criminal act that "reflects adversely on the lawyer's honesty, trustworthiness or fitness as a lawyer . ..."26 Under this analysis, Comment [2] does not seem to apply to "conduct involving dishonesty, fraud," etc., under subsection (c), but only to criminal conduct which involves moral turpitude under subsection (b). On the other hand, all fraud, misrepresentation and deceit are proscribed by the literal language of Rule $8.4(\mathrm{c})$ (which is not limited to conduct affecting a lawyer's fitness to practice). ${ }^{27}$

The Model Rules further prohibit a lawyer from using a proxy to indirectly do that which the lawyer may not do directly. As noted above, Rule 8.4 (a) provides that a lawyer may not knowingly violate a disciplinary rule, "or do so through the acts of another." 28 Comment [1] to the same rule provides that lawyers may not violate the Model Rules "through the acts of another, as when they request or instruct an agent to do so on the lawyer's behalf." 29 In addition, Model Rule 5.3 provides that lawyers are responsible for the actions of nonlawyers and subordi-

23. Id. at 817.

24. Id. at 801-04.

25. See infra Part V. For example, Virginia amended its version of Model Rule 8.4 to prohibit that deception "which adversely affects an attorney's fitness to practice law." See VA. RULES of PROF'L CONDUCT R. 8.4 (2008).

26. Thomas H. Moore, Can Prosecutors Lie?, 17 Geo. J. LEGAL ETHICS 961, 970 (2004). According to Moore, "Comment 2 clearly speaks only to 'illegal activity,' which is the subject of Model Rule 8.4(b). Rule 8.4(b) is also the only section of Rule 8.4 that refers to 'the lawyer's ... fitness as a lawyer." Id at 971 . While Moore is probably literally correct, this does not solve the problem posed by this Article: if deception is to be permitted, the Rules should be amended, as argued below.

27. Model Rule 4.1, entitled "Truthfulness in Statements to Others," forbids a lawyer from knowingly making "a false statement of material fact or law ..." or failing to disclose a material fact when necessary to avoid assisting in client fraud or crime. MODEL RULES R. 4.1; see also ABA Comm. on Ethics and Prof'l Responsibility, Formal Opinion 06-439 (2006) (discussing a lawyer's duty to avoid misrepresentations during settlement negotiations).

28. MODEL RULES R. 8.4(a).

29. Id. cmt.1. 
nate lawyers they supervise. A lawyer who retains associates or employs a nonlawyer-including an investigator-"shall make reasonable efforts to ensure that the person's conduct is compatible with the professional obligations of the lawyer." of an investigator that the lawyer orders, approves, or ratifies. ${ }^{31}$

We will now consider the ABA Model Code of Professional Responsibility (the "Code"), which antedated the Model Rules. Like the subsequent Model Rules, the Code similarly prohibits deceit and misrepresentations. ${ }^{32}$ Disciplinary Rule 1-102(a)(2) provides: "A lawyer shall not: ... [e]ngage in illegal conduct involving moral turpitude. ${ }^{, 33}$ DR 1102(A)(3) of the Code provides: "A lawyer shall not ... [e]ngage in conduct involving dishonesty, fraud, deceit, or misrepresentation." 7-102(A)(5) provides, "In the representation of a client, a lawyer shall not ... [k]nowingly make a false statement of law or fact."35 Thus, like the Model Rules, the Code proscribes lawyer conduct involving fraud, misrepresentation, and deception.

\section{B. The No-Contact Rule}

Model Rule 4.2, also known as the "no-contact" rule, ${ }^{36}$ bars an attorney from communicating with represented adverse parties:

In representing a client, a lawyer shall not communicate about the subject of the representation with a person the lawyer knows to be represented by another lawyer in the matter, unless the lawyer has

30. MODEL RULES R. 5.3(b).

31. MOdel Rules R. 5.3(c); see also Rebecca Graves Payne, Investigative Tactics: They May Be Legal, But Are They Ethical?, 35 JAN COLO. LAw. 43 (2006).

32. The Code is discussed here because it informs many of the earlier decisions discussed in this Article, including decisions from New York, Colorado, and Oregon. In 2007, the New York State Bar Association approved the recommendation of its Committee on Standards of Attorney Conduct to adapt the Model Rules format. The changeover is still subject to approval of New York's Appellate Division.

33. MODEL CODE OF PROF'L RESPONSIBILITY DR 1-102(a)(3) (1969). [hereinafter MODEL CODE]. In New York, the Disciplinary Rules of the Code of Professional Responsibility more broadly provides as follows: "A lawyer or law firm shall not ... [e]ngage in illegal conduct that adversely reflects on the lawyer's honesty, trustworthiness or fitness as a lawyer." 22 NEW YORK CODE OF PROF'L RESPONSIBILITY $\S 1200.3(A)(3)$ (2008) [hereinafter NY CODE].

34. MODEL CODE DR 1-102(a)(4). New York's rule is similar, except that it extends the prohibition to "a lawyer or law firm." NY CODE $§ 1200.3(A)(4)$

35. MODEL CODE DR 1-102(a)(5) (cited in RICHARD A. ZITRIN ET AL., LEGAL ETHICS: RULES, STATUTES AND COMPARISONS 495 (Lexis Nexis 2008)). The New York Code provision is the same. NEW YORK LAWYER'S CODE OF PROF'L RESPONSIBILITY DR 7-102(A)(5); NY CODE $\$ 1200.33(\mathrm{~A})(5)$.

36. See generally Lisa G. Lerman \& Philip G. Schrag, Ethical Problems in the PRACTICE OF LAW 695 n.25 (2d ed. 2008) (referring to "anti-contact" rule); Julian J. Moore, Home Sweet Home: Examining the (Mis)Application of the Anti-Contact Rule to Housing Discrimination Testers, 25 J. LEGAL Prof. 75 (2001). 
the consent of the other lawyer or is authorized to do so by law or a court order. ${ }^{37}$

This Rule is important to our analysis, as the use of deception in many undercover investigations is often intertwined with attorney contact with represented parties.

The comments to Model Rule 4.2 indicate that it is not intended to bar contact with all representatives of an adverse, represented organization: ${ }^{38}$

In the case of a represented organization, this Rule prohibits communications with a constituent of the organization who supervises, directs or regularly consults with the organization's lawyer concerning the matter or has authority to obligate the organization with respect to the matter or whose act or omission in connection with the matter may be imputed to the organization for purposes of civil or criminal liability." 39

Violations of the no-contact rule have sometimes, but not always, resulted in suppression of evidence improperly obtained, and sanctions against the supervising lawyers. ${ }^{40}$

While a detailed analysis of the no-contact rule is outside the scope of this Article, the Eighth Circuit's decision in Midwest Motor Sports v. Arctic Cat Sales, Inc., is illustrative. ${ }^{41}$ That case involved a commercial dispute between a franchisor of snowmobiles and its former franchisee, a retail snowmobile dealer. ${ }^{42}$ The former dealer claimed that it had been unfairly cashiered in favor of another, competing dealer. ${ }^{43}$ The case was in litigation, the parties were represented by counsel, and discovery was ongoing. Nonetheless, the franchisor's attorneys dispatched an undercover investigator to view the franchisees' showroom and surreptitiously tape record conversations with its sales staff. ${ }^{44}$ Without revealing his identity, the investigator posed as a consumer and queried the sales staff, as well as the president of the terminated dealer, who was an adverse party represented by counsel. ${ }^{45}$

Because the investigator was dispatched by counsel, the conduct was improper. The investigator's purpose "was to elicit specific admis-

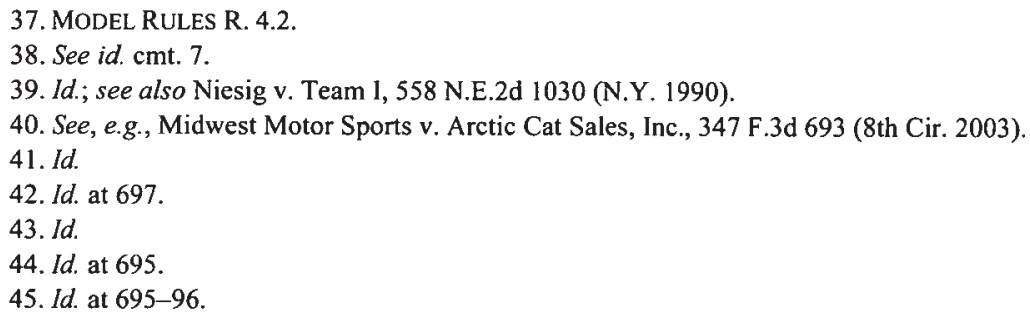


sions" from an adverse, represented party on issues relevant to the litigation "that could have been obtained properly through the use of formal discovery techniques." ${ }^{.46}$ In fact, the franchisor had recently served a discovery request for some of the information sought by its investigator. $^{47}$ The attorney's use of an investigator in essence circumvented orderly discovery procedures. Thus, the conduct in Midwest Motor Sports violated the no-contact rule. ${ }^{48}$

The no-contact rule has also been applied to the conduct of federal prosecutors. In U.S. v. Hammad, an assistant United States attorney instructed a cooperating informant to surreptitiously wear a wire in order to obtain incriminating evidence from the target of a fraud investigation. ${ }^{49}$ The informant handed the target a sham subpoena prepared by the assistant United States attorney. ${ }^{50}$ After he was arrested, the target sought to suppress the evidence obtained by the informant. He argued that during the investigation he had been represented by counsel; therefore, the government had, by proxy, violated DR 7-104(A)(1) of the Code of Professional Responsibility, which prohibits attorneys from knowingly contacting represented adverse parties. ${ }^{51}$ The district court granted the motion to suppress, reasoning that the informant was the government's "alter ego," but the court of appeals reversed. ${ }^{52}$ The court rejected the government's contention that the no-contact rule "is inapplicable to criminal investigations under any circumstances," finding instead that it may indeed apply and that it was violated on the facts of the case before it. ${ }^{53}$ Determined to hedge its bets, the court considered the "authorized by law" exception to DR 7-104, and reasoned that a prosecutor is " authorized by law' to employ legitimate investigative techniques in conducting or supervising criminal investigations, and the use of informants to gather evidence against a suspect will frequently fall within the ambit of such authorization.. ${ }^{54}$ Nonetheless, the government violated the no-contact rule by giving the informant a fake subpoena "to create a pretense that might help the informant elicit admissions from a represented suspect." 55 While finding a breach of the disciplinary rules, the court of appeals de-

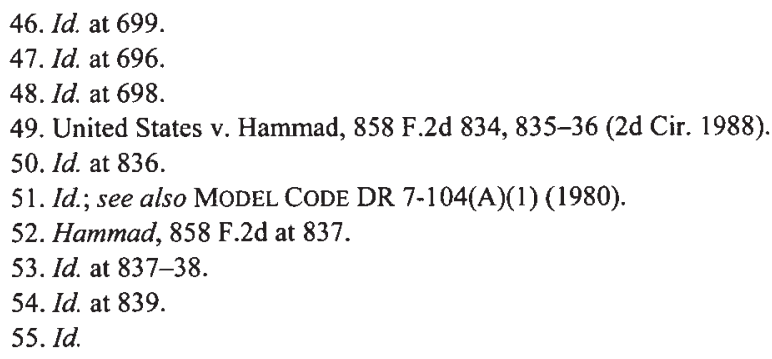


clined to exclude the evidence due to the unsettled nature of the law in the area. ${ }^{56}$

\section{THE ZERO TOLERANCE ZONE: NO SUBJECT-MATTER EXCEPTIONS}

Some authorities, as we will see, have recognized some societal goals that are sufficiently important to justify the use of undercover investigations involving deception. ${ }^{57}$ Other authorities, in contrast, have announced a zero tolerance policy for attorney deceit in investigations. ${ }^{58}$ These authorities reason that the Model Rules clearly proscribe deception, misrepresentation, and deceit. ${ }^{59}$ To put it simply, lying is morally and ethically wrong, and lawyers shouldn't do it.

\section{A. May Lawyers Ever Lie?}

Many commentators have reflected on the tension between the lawyer's duty of zealous advocacy to clients and the duty to refrain from misrepresentations and deceit. ${ }^{60}$ There are more than a few judges who take a dim view of attorneys who resort to deception. ${ }^{61}$ Some commentators have posited that lawyers should never lie, that lying is morally and ethically wrong, and that it is never justified, even to save a human life. ${ }^{62}$ Many lawyers have bemoaned the profession's loss of prestige and note that the general public views lawyers as less than truthful. ${ }^{63}$

Philosopher Sissela Bok has argued that deception can be morally justified in some circumstances, e.g., to save a human life, or when sur-

56. Id. at 842 .

57. See, e.g., Isbell \& Salvi, supra note 22; Apple Corps Ltd. v. Int'l Collectors Soc'y, 15 F. Supp. 2d 456, 475 (D.N.J. 1998).

58. In re Pautler, 47 P.3d 1175 (Colo. 2002) (en banc); In re Malone, 105 A.D.2d 455, 455 (N.Y. 1984)

59. Pautler, 47 P.3d 1175 .

60. See, e.g., W. William Hodes, Seeking the Truth Versus Telling the Truth at the Boundaries of the Law: Misdirection, Lying and "Lying With An Explanation", 44 S. TEX. L. REV. 53 (2002).

61. Pautler, 47 P. 3d 1175; Malone, 105 A.D.2d 455.

62. See generally Rebecca B. Cross, Ethical Deception by Prosecutors, 31 FordHAM URB. L.J. 215,230 (2003) (collecting authorities on whether lying is ever permitted, and concluding that some circumstances do permit deception). See also Bonsignore, supra note 14 (stating that "(1) a lawyer should play no part in dissemblance, except under extreme duress, especially in hiring or being affiliated with an investigator who engages in deceptive tactics while working for that attorney; (2) when a lawyer engages in, authorizes or otherwise participates in dissemblance directly or indirectly, he or she undermines the values of the American adversarial legal system.").

63. See E. Cliff Martin \& T. Karena Dees, The Truth About Truthfulness: The Proposed Commentary to Rule 4.1 of the Model Rules of Professional Conduct, 15 GEO. J. LEGAL ETHICS 777, 779

(2002) (reporting that "a poll revealed that one-third of the American public thinks that lawyers are less truthful than most people"). 
vival is otherwise at risk. ${ }^{64}$ Some legal scholars posit that deception and misdirection are inherent in the practice of law, and/or are justified by the important social values of enforcing the law or fighting discrimination. ${ }^{65}$ As mentioned above, David Isbell and Lucantonio Salvi have argued that Model Rule 8.4 does not proscribe all deceit and misrepresentation, but only that which rises to the level of what used to be known as moral turpitude. ${ }^{66}$ According to these authors, the proscription in Rule 8.4 (c) "should apply only to grave misconduct that would not only be generally reproved if committed by anyone, whether lawyer or nonlawyer, but would be considered of such gravity as to raise questions as to a person's fitness to be a lawyer." 67 This approach, which would approve deception under some circumstances, has had some traction with state bar associations and ethics committees.

This Article accepts the proposition that some level of deception is acceptable by attorneys acting through investigators. The strongest case for undercover investigations is presented by the federal prosecutor supervising an undercover investigation of a terrorist ring. However, once a single court approves any use of deception by any lawyer, it is fair to debate the use of deception in other areas of the law by other lawyers.

The tension between lawyers' several conflicting duties forms a backdrop for ongoing debates in the various states-as well as nationally-about whether attorneys may resort to deception under any circumstances. For example, in Colorado, the state supreme court refused to carve out a law enforcement exception to the honesty provisions of the state ethics code. ${ }^{68}$ Two other jurisdictions have sanctioned law enforcement officers who coached witnesses to lie under oath. ${ }^{69}$ And in Oregon, an absolutist prohibition on attorney deception in investigations resulted in a rule change explicitly permitting undercover investigations without reference to the underlying subject matter of the claim or case. ${ }^{70}$ The following section will examine these authorities from Colorado, Oregon, New York, and Illinois.

64. Sissela BoK, Lying: Moral Choice in Public and Private Life 108-09 (Vintage Books 1989). Bok argues that lying to save an innocent life is morally justified. Id. at 109. However, she expresses doubt about whether lying can be otherwise justified in the name of the public good. Id. at 176-80.

65. Cross, supra note 62; Monroe H. Freedman, In Praise of Overzealous RepresentationLying to Judges, Deceiving Third Parties, and Other Ethical Conduct, 34 HOFSTRA L. REV. 771, 772 (2006).

66. Isbell \& Salvi, supra note 22

67. Id. at 817 .

68. See In re Pautler, 47 P.3d 1175 (Colo. 2002) (en banc).

69. In re Malone, 105 A.D.2d 455, 455 (N.Y. 1984); In re Friedman, 392 N.E.2d 1333 (III. 1979).

70. See infra Part III.D; In re Gatti 8 P.3d 966 (Or. 2000). 
B. In re Pautler: The Deception Which Helped Capture an Axe Murderer

The unforgettable facts of In re Pautler arose in rural Colorado. ${ }^{71}$ William Neal was a multiple axe murderer. ${ }^{72} \mathrm{He}$ murdered three women and raped a fourth, whom he was holding as a hostage. ${ }^{73}$ In a telephone conversation with Colorado police authorities while he was still at large, Neal agreed to surrender, but only if represented by counsel. ${ }^{74}$ The police asked Mark Pautler, Chief Deputy District Attorney of Jefferson County, Colorado, to help apprehend Neal. Pautler picked up the phone and impersonated a public defender, inventing the fictitious name, "Mark Palmer." N5 Neal told the fictitious "Palmer" that he would surrender if he would be separated from other detainees, permitted to smoke, and in the presence of his lawyer when he surrendered. ${ }^{76}$ Pautler told the suspect, "Right, I'll be present.", When Neal questioned the ersatz "Palmer" about his rights, Pautler demurred. ${ }^{78}$ Neal surrendered without incident. $^{79}$

Pautler did not reveal his deception to Neal. ${ }^{80}$ Following Neal's arraignment, the real public defender appointed to defend Neal recognized Pautler's voice on a tape recording of the surrender negotiations and reported the deception to the court. ${ }^{81}$ The incident so rattled Neal that he discharged his public defender and proceeded to be convicted and sentenced to death in a trial in which he represented himself pro se. ${ }^{82}$

For his role in the deception of Neal, Pautler, the prosecutor, was himself prosecuted by the Colorado attorney disciplinary authorities. Those authorities imposed discipline on Pautler, including a stayed suspension, additional ethics education, and a retaking of the multistate professional responsibility examination. ${ }^{83}$ Pautler argued that his deception was justified because he was acting in his capacity as a law enforcement officer, and because the situation presented a threat of "imminent public harm," as Neal was a killer on the lam who had taken hostages. ${ }^{84}$

71. Pautler, 47 P. $3 d 1175$.
72. Id. at $1176-77$.
73. Id.
74. Id. at 1177.
75. Id.
76. Id.
77. Id.
78. Id. at $1177-78$.
79. Id. at 1178.
80. Id.
81. Id.
82. Id.
83. Id.
84. Id. at $1179-82$.


The Colorado Supreme Court upheld the discipline, finding that Pautler had lied to the suspect in violation of Colorado RPC 8.4(c), which prohibits fraud, deceit or misrepresentation. ${ }^{85}$ The court stated that "even a noble motive does not warrant departure from the Rules of Professional Conduct," and that "prosecutors cannot involve themselves in deception, even with selfless motives." ment that Pautler had no alternative to deception, noting that he could have made additional efforts to locate a real defense lawyer. ${ }^{87}$ Rather, the court stated:

[W]e reaffirm that members of our profession must adhere to the highest moral and ethical standards. Those standards apply regardless of motive. Purposeful deception by an attorney licensed in our state is intolerable, even when it is undertaken as a part of attempting to secure the surrender of a murder suspect. A prosecutor may not deceive an unrepresented person by impersonating a public defender. ${ }^{88}$

In short, Pautler was publicly disciplined for using deception in an effort to induce a murderer to surrender. The Pautler case, while causing a national stir among ethicists and prosecutors, did not result in a rule change or ethics opinion in Colorado.

\section{$C$. In re Malone and In re Friedman:}

Coaching a Witness to Lie Under Oath

Brian Malone, like Mark Pautler, was a public servant with unselfish motives. As Inspector General of the New York State Department of Correctional Services, Malone, also an attorney, investigated the brutal beating of an inmate by several corrections officers. ${ }^{89}$ Malone obtained the cooperation of one corrections officer who witnessed the incident but was concerned that the "code of silence" among law enforcement officers would stymie his investigation if other officers learned of the cooperation. ${ }^{90}$ He was also concerned about possible retaliation against this cooperating witness. ${ }^{91}$ In order to maintain the secrecy of the witness's identity, and to avoid witness intimidation, Malone told the cooperating witness to give a false sworn statement in which he denied

85. Id. at 1184; see COLO. RULES OF PROF'L CONDUCT R. 8.4(c) (2008).

86. Pautler, 47 P.3d at 1180 .

87. Id. at 1180 .

88. Id. at 1176 .

89. In re Malone, 105 A.D.2d 455, 455 (N.Y. App. Div. 1984)

90. Id.

91. Id. 
witnessing the use of excessive force on the complaining prisoner. ${ }^{92} \mathrm{Ma}-$ lone secretly took a truthful version of the witness's statement on another occasion. $^{93}$

Malone filed disciplinary charges against the perpetrating officers, and the erstwhile secret witness testified at an arbitration hearing, whereupon he first revealed the existence of the two contradictory statements. ${ }^{94}$ Malone was charged with violating New York's Disciplinary Rule 1-102 for instructing a witness to give false testimony. ${ }^{95}$ In his defense, he admitted to counseling the false testimony, but argued that his advice was justified by his desire to protect the identity and safety of the witness, to prevent witness tampering, and to pursue an important investigation into prison brutality. ${ }^{96}$ While acknowledging that Malone "appears to have acted out of a laudable motive, namely, to protect a witness willing to risk retaliation for breaking the correction officers' 'code of silence,","97 the appellate division rejected his justification defense and publicly censured Malone, noting that there were alternative methods to secure the identity of the witness short of suborning perjured testimony. ${ }^{98}$ The court further observed that the defense of justification, while applicable to the defendant in a criminal prosecution, did not excuse unethical conduct by a lawyer. ${ }^{99}$

A similar analysis was applied in In re Friedman, ${ }^{100}$ in which a prosecutor instructed a witness to lie under oath in order to consummate a bribery case against a corrupt lawyer. ${ }^{101}$ In exchange for a $\$ 50$ bribe from a corrupt defense lawyer, a police officer falsely informed the presiding judge in a drunk driving case that the police department's breathalyzer operator would be unavailable to testify in court. ${ }^{102}$ This false

92. Id. at $455-56,480$ (stating that it was unusual "for a correction officer to voluntarily inform upon his fellow officers for fear of retaliation for breaking the 'code of silence' which exists among correction officers").

93. Id. at 456 .

94. Id. at $456-57$.

95.1d.

96. Id. at $458-60$.

97. Id. at 460 .

98. Id. at $458-59$.

99. Id. at 459. It could even be argued that the creation of false testimony was worse than unnecessary; it was counterproductive to the government's aims. The creation of a swom inconsistent statement by the government's star witness would have instantly shattered the credibility of that witness. A witness who is willing to lie under oath at the direction of a lawyer is still a liar. Thus, it is difficult to understand what the inspector general thought he was accomplishing by creating a double, contradictory record in Malone.

100. In re Friedman, 392 N.E.2d 1333 (III. 1979).

101. Id. at 1334

102. Id. 
statement was approved by Friedman, the prosecutor, specifically to make out a case against the corrupt lawyer who paid the bribe. ${ }^{103}$

Friedman argued that his conduct was justified in order to consummate the bribery investigation of corrupt lawyers, and was permitted by analogy to cases permitting subterfuge in undercover narcotics investigations. ${ }^{104}$ However, the Illinois Supreme Court drew the line at the courthouse door: "The integrity of the courtroom is so vital to the health of our legal system that no violation of that integrity, no matter what its motivation, can be condoned or ignored." 105 While the majority found that Friedman had violated the Code, it declined to impose a sanction due to the lack of authority on the subject. ${ }^{106}$

Of course, the act of suborning perjury is of a very different order of magnitude from misrepresenting one's identity. And the courts that have explicitly considered the issue from the standpoint of attorney ethics have said that a lawyer may not permit or use perjury, let alone encourage it. ${ }^{107}$

\section{In re Gatti: The Lawyer Who Posed as a Chiropractor}

In re Gatti ${ }^{108}$ prompted much hand-wringing and, ultimately, a revision of the Oregon Code of Professional Conduct. ${ }^{109}$ It also resulted in a categorical refusal to create status-based exceptions to the state disciplinary rules proscribing deception. ${ }^{10}$

Daniel Gatti, an Oregon lawyer, represented chiropractors under criminal investigation by state prosecutors. ${ }^{11}$ The government lawyers sent undercover investigators, posing as injured patients or janitors, into the offices of Gatti's chiropractor clients, where those investigators gath-

103. See id.

104. Id. at. $1334-35$.

105. Id. at 1335 .

106. Id. at 1339.

107. Yet federal prosecutors and FBI agents, all of whom were lawyers, fabricated a bevy of crimes and presented the court with false testimony in Operation Greylord. All of the convictions were affirmed. As a Seventh Circuit court stated in affirming the conviction of a judge:

In Operation Greylord agents of the FBI took the stand in the Circuit Court of Cook County and lied about their made-up cases. Perjury is a crime, and [defendant] Murphy tells us that those who commit crimes themselves cannot prosecute others' crimes. But criminal proceedings are not designed to establish the relative equities among police and defendants. In many categories of cases it is necessary for the agents to commit acts that, standing by themselves, are criminal.

United States v. Murphy, 768 F.2d 1518, 1528 (7th Cir. 1985); see also Robert Blecker, Beyond 1984: Undercover in America-Serpico to Abscam, 28 N.Y.L. SCH. L. REV. 823 (1984).

108. 8 P.3d 966 (Or. 2000).

109. See discussion infra Part III.E.

110. Gatti, 8 P.3d at 975 .

111. Id. at 969 . 
ered evidence of criminal wrongdoing. ${ }^{112}$ Gatti filed an ethics complaint against the prosecutors supervising the investigation, arguing that the infiltration of his clients' offices under false pretenses was deceptive in violation of the Lawyer's Code of Professional Responsibility. ${ }^{13}$ The state bar disciplinary board declined to take action, observing that, while there was no authority directly on point, "[o]ur preliminary conclusion is that if [the prosecuting agency] is considered to have public authority to root out possible fraud, then attorneys assisting [it] in this endeavor are not acting unethically in providing advice on how to conduct a legal undercover operation." 114 The state bar counsel further opined that it was not aware of any distinction between the standards of conduct applicable to public- versus private-sector attorneys. ${ }^{115}$

Emboldened by the apparent green light from the state bar counsel, Gatti undertook his own investigation of fraudulent medical review practices by a medical agency. He telephoned the agency and one of its reviewing chiropractors under false pretenses. ${ }^{116}$ Gatti identified himself as a chiropractor and obtained information in tape-recorded conversations, which he ultimately used to launch a federal civil lawsuit alleging fraud against the medical reviewing agency. ${ }^{117}$ In the taped conversations, Gatti told the agency "that he was interested in working for CMR [the medical review agency], that he was a doctor, that he saw patients, that he performed independent medical examinations, and that he was interested in becoming involved with CMR's educational seminars."118 Thus, Gatti lied about his identity and purpose.

Upon learning of Gatti's deception, the medical agency filed a grievance against him with the state bar, contending that he had violated DR 1-102 of the Oregon Code by engaging in "conduct involving dishonesty, fraud, deceit or misrepresentation."119 Gatti responded that he reasonably relied upon the bar counsel's written response to his own earlier complaint against the government attorneys investigating his clients, and that he reasonably deduced from that response that the use of deception in undercover investigations was appropriate and proper by either government or private attorneys. ${ }^{120}$ In other words, what is sauce for the goose is sauce for the gander. While this argument prevailed before the

112. See id.

113. Id.

114. Id. at 969.

115. Id. at 974.

116. Id. at 970.

117. Id.

118. Id. at 972 .

119. Id. at 973.

120. Id. 
bar counsel, it was rejected by the Oregon Supreme Court, which held that Gatti's reliance on the bar counsel's prior letter was not reasonable. ${ }^{121}$ Rather, the court wrote, "[t]he Bar's letters neither stated nor implied that lawyers in the private practice of law may misrepresent their identity or purpose in investigating a matter." 122 On the merits, the court found that Gatti had affirmatively misrepresented his identity to the medical agency. ${ }^{123}$ Gatti further lied by stating that "he saw patients and performed independent medical examinations, which he [did] not do, and that he was interested in working for CMR, when in fact he was not." 124

During the proceedings on appeal, the U.S. Attorney for the District of Oregon filed an amicus curiae brief asking the Oregon Supreme Court to carve out an exception permitting the use of deception in undercover law enforcement operations that "involve both civil and criminal cases, ranging from enforcement of civil rights statutes to international narcotics conspiracies." "25 Various civil rights organizations requested the right to use deception in undercover investigations of housing discrimination. ${ }^{126}$ Thus, government prosecutors and civil rights advocates asked the court to create two status-based exceptions.

The court rejected these arguments and broadly held that deception of any type was prohibited by the literal language of the code: "Faithful adherence to the wording of DR 1-102(A)(3), DR 7-102(A)(5), ORS 9.527(4), and this court's case law does not permit recognition of an exception for any lawyer to engage in dishonesty, fraud, deceit, misrepresentation, or false statements." 127 The Code's proscriptions on deceit and misrepresentations "apply to all members of the Bar, without exception." 128 Thus, the court declined to draw a status-based exception to the Oregon honesty rule. Gatti was reprimanded. But that was not the end of the story.

\section{E. The Oregon Response to Gatti}

Following the Oregon Supreme Court's decision in Gatti, which rejected the Justice Department's request for an express carve-out for crim-

121. Id. at $979-80$.

122. Id. at 972.

123. Id. at 974 .

124. Id.

125. Id. at $974-75$.

126. Id. at 975; see also Jesse W. Barton, A Remedy for Gatti, OR. STATE BAR BULLETIN 70 (November 2001), available at http://www.osbar.org/publications/bulletin/01 nov/parting.htm (referencing proposed bill to permit undercover investigations by civil rights agencies and law enforcement agencies).

127. Gatti, 8 P.3d at 976 .

128. Id. 
inal law enforcement, ongoing undercover criminal investigations in the state ground to a halt. ${ }^{129}$ Several federal criminal investigations were halted midway. ${ }^{130}$ The Justice Department filed suit to enjoin the Oregon Bar from enforcing DR 1-102 against federal prosecutors involved in criminal undercover operations. ${ }^{131}$

As the suit was pending, the Oregon State Bar-a unified bar in which membership is mandatory for all Oregon lawyers-scrambled to revise its ethics code. ${ }^{132}$ The law enforcement community proposed an amendment to the rules, which would exempt government lawyers from the ban on deceit and misrepresentation. ${ }^{133}$ Not to be left out, civil rights lawyers proposed expanding the exemption to lawyers for "publicly funded civil rights enforcement agencies, including nonprofit organizations such as legal services offices." 134 The Oregon Bar rejected these carve-outs.

In 2002, Oregon amended its ethics rules to permit the use of indirect deception in undercover operations by all lawyers, regardless of status of the lawyer or nature of the claim. ${ }^{135}$ As amended, the Oregon ethics rules provide that a lawyer may not "engage in conduct involving dishonesty, fraud, deceit or misrepresentation that reflects adversely on the lawyer's fitness to practice law."136 The italicized portions were add-

129. Moore, supra note 26, at 964.

130. See id.

131. Oregon State Bar, 2001 House of Delegates Meeting: Agenda I 9 (September 22, 2001), available at $\mathrm{http}: / / \mathrm{www} .0$ bbar.org/leadership/hod/2001/901 agenda.htm. The Justice Department suit sought a declaratory judgment that "the Supremacy Clause bars any application to federal attorneys of DR 1-102 and DR 7-102" of the Oregon Ethics Code, as interpreted by the Oregon Supreme Court in Gatti. Id.; OREGON STATE BAR, BAR LEADER COMMUNICATOR, June 7, 2001, at 1, available at http://www.osbar.org/_docs/blc/blc_01June7.pdf (Oregon State Bar voting to defend itself against federal suit).

132. Barton, supra note 126.

133. Id.

134. Id.

135. In January 2002, the Oregon Supreme Court approved an amendment to DR 1-102, to provide that "it shall not be professional misconduct for a lawyer to advise clients or others about or to supervise lawful covert activity in the investigation of violations of civil or criminal law or constitutional rights, provided the lawyer's conduct is otherwise in compliance with these rules." OR. CODE OF PROF'L RESPONSIBILITY DR 1-102 (2003); Sylvia E. Stevens, New (and Evolving) Developments in the Disciplinary Rules, OR. STATE BAR BULlETIN 27 (Apr. 2002); Arthur Garwin, Covert Work OK, 1 NO. 6 A.B.A. J. E-REPORT 9 (2002). Oregon subsequently changed its rules to convert to the ABA Model Rules format, and added language to its new rule 8.4(a)(3) banning only that deception "that reflects adversely on the lawyer's fitness to practice law." Oregon State Bar Ass'n Bd. of Governors, Formal Op. 2005-173 (2005), available at http://www.osbar.org/_docs/ ethics/2005-173.pdf [hereinafter Or. Ethics Op.].

136. OR. RULES OF PROF'L CONDUCT R. 8.4(a)(3) (2006) (emphasis added). 
ed in 2002, subsequent to the Oregon court's decision in Gatti. ${ }^{137}$ The new Oregon rule explicitly provides that lawyers may ethically supervise undercover investigations in which they themselves do not directly participate:

[I]t shall not be professional misconduct for a lawyer to advise clients or others about or to supervise lawful covert activity in the investigation of violations of civil or criminal law or constitutional rights, provided the lawyer's conduct is otherwise in compliance with these Rules of Professional Conduct. "Covert activity," as used in this rule, means an effort to obtain information on unlawful activity through the use of misrepresentations or other subterfuge. ${ }^{138}$

The protection of the revised rule is available only "when the lawyer in good faith believes there is a reasonable possibility that unlawful activity has taken place, is taking place or will take place in the foreseeable future."139 Thus, in response to Gatti, Oregon promulgated a revised rule that permits the use of deception and "subterfuge" by lawyers, without distinction between public and private sector lawyers. The lawyer must have a good faith belief that there is a reasonable possibility of unlawful activity-without regard to the substantive subject matter of the client's underlying claim. The investigation may be supervised by the lawyer, who may not, however, directly participate in it.

The revised Oregon law, by its terms, clearly permits undercover operations to investigate violations of criminal law, by either the prosecution or the defense. ${ }^{140}$ It would also permit subterfuge to probe any civil law violation, or violation of civil rights, without specifying the limitations on either. It is not clear how far the rule reaches. Would any civil law violation justify deception in Oregon? The classic examples would be testers for housing or employment discrimination, or in trademark infringement cases. What about the investigation of civil fraud? For example, Daniel Gatti himself was purportedly involved in an investigation of fraud by a medical review agency. ${ }^{141}$ Would that investigation justify the use of deception under the new rule? Fraud is a violation of civil and, in some circumstances, criminal law, and an investigation of billing practices would seem to comply at least facially with the revised rule. Indeed, any tort could be characterized as a violation of civil law.

137. January 2002 Special House of Delegates Meeting: Agenda (January 18, 2002), available at http://www.osbar.org/leadership/hod/2002/agendaJan02.html (detailing resolutions to be voted on in upcoming meeting).

138. OR. RULES OF PROF'L CONDUCT R. 8.4(b).

139. Id.

140. See id.

141. See In re Gatti, 8 P.3d 966, 969 (Or. 2000). 
An ethics opinion by the Oregon State Bar Association clarified some of these issues by the use of three hypotheticals. ${ }^{142}$ In the first hypothetical scenario, the Oregon committee opined that a lawyer could not advise a client to use subterfuge to investigate the denial of a worker's compensation claim, because there was no unlawful activity or violation of law. ${ }^{143}$ In a second hypothetical scenario, the committee opined that a defense lawyer in a personal injury case could not directly deceive the physician for a purported malingerer who was suspected of exaggerating or falsifying injuries. ${ }^{144}$ While in this instance there was evidence of a legal violation, the lawyer could not ethically participate directly in the subterfuge, but was limited to advising the client and "supervising" the investigation. ${ }^{145}$ In a third hypothetical, a prosecutor could ethically supervise police officers in an undercover drug buy operation based upon probable cause to believe that illegal drug activity was underway. ${ }^{146}$ Thus, the Oregon Bar illustrated that its new rule is limited to indirect participation by lawyers in investigations where there is evidence of unlawful activity.

Oregon has eliminated status-based distinctions and created a broad-based rule which permits indirect deception by lawyers to investigate unlawful conduct, regardless of the substantive subject-matter of the client's underlying claim or defense. Other states, discussed infra in Part $\mathrm{V}$, have come up with a patchwork of status-based distinctions that contain incremental measures, few of which provide much guidance for practitioners, unless you happen to be a prosecutor or a CIA agent.

\section{STATUS-BASED EXCEPTIONS IN SUBSTANTIVE SUBJECT AREAS}

This Part will now examine three substantive areas of the law in which undercover investigators are frequently supervised by lawyers: criminal law, intellectual property, and civil rights. These are substantive areas in which some degree of deception is often considered necessary in order to investigate and prosecute affirmative claims for violation of the law.

142. See Or. Ethics Op., supra note 135. This is a revision of Oregon Ethics Opinion 2003173, which was decided under the prior Oregon Code of Professional Responsibility. Compare id. with Oregon State Bar Ass'n Bd. of Governors, Formal Op. 2005-173 (2003).

143. Or. Ethics Op., supra note 135.

144. Or. Ethics Op., supra note 135, at 3-4.

145. Id. at 4 . This second hypothetical is actually very similar to the facts of $I n$ re Gatti itself, and suggests that the same result would be obtained under the revised rules, due to the lawyer's direct involvement in the deception.

146. Id. at 5-6. 


\section{A. Criminal Law}

The use of deception by government lawyers in undercover criminal investigations has been recognized by a number of authorities. Fred C. Zacharias and Bruce A. Green have observed that "prosecutors routinely direct law enforcement agents to mislead suspects about the agents' identities and goals." ${ }^{147}$ In Apple Corps Ltd. v. International Collectors Society, the U.S. District Court for the District of New Jersey acknowledged that " $[\mathrm{u}]$ ndercover agents in criminal cases and discrimination testers in civil cases, acting under the direction of lawyers, customarily dissemble as to their identities or purposes to gather evidence of wrongdoing." 148

The use of deception by law enforcement authorities has a long history. As early as 1932, the United States Supreme Court, in its first case recognizing the entrapment defense, ${ }^{149}$ noted that "[a]rtifice and stratagem may be employed to catch those engaged in criminal enterprises." 150 Maurice Nadjari, a controversial former New York State Special Prosecutor, explained: "When you're involved with drug sellers, you have to go out and buy drugs. When judges are selling fixes, you have to go out and buy the fix. That is the only way to do it." 151

As Robert Blecker has comprehensively described, the use of deception by government agents posing as criminals has ranged from the use of manufactured crimes in New York City in the 1970s, to the famous Abscam scandal in which government informants and agents, posing as Arab sheiks, bribed U.S. Congressmen in front of FBI video cameras. ${ }^{152}$ In Abscam, federal agents set up and funded a dummy front corporation called "Abdul Enterprises." J53 Justice Department lawyers supervised and advised the undercover agents during the course of the sting operation. ${ }^{154}$ Six congressmen, a United States Senator, the mayor of

147. Fred C. Zacharias \& Bruce A. Green, The Uniqueness of Federal Prosecutors, 88 GEo. L.J. 207, 231 (2000).

148. 15 F. Supp. 2d 456, 475 (D.N.J. 1998).

149. See Sorrells v. United States, 287 U.S. 435, 443 (1932).

150. See id. at 441 . In that case, the entrapment defense was recognized where an undercover federal revenue agent repeatedly importuned the defendant to fetch him contraband liquor. The federal agent lured the suspect into committing the crime "by repeated and persistent solicitation in which he succeeded by taking advantage of the sentiment aroused by reminiscences of their experiences as companions in arms in the [first] World War." Id. at 441. This was a "gross abuse of authority." Id.

151. Marcia Chambers, Court Condemns Nadjari Methods, N.Y. TimES, Dec. 14, 1974, at Al.

152. Blecker, supra note 107, at 872-73. One U.S. Congressman was captured on tape bragging that, "I have larceny in my blood." Id. at 887.

153. See id. at 873.

154. See id. at 882,956 . DOJ lawyers even advised government informants and agents as to the amount of bribes to offer. $I d$. 
Camden, New Jersey, and various Philadelphia city councilmen were convicted of bribery. ${ }^{155}$ The indicted congressmen argued entrapment; their constitutional due process rights were allegedly violated because they were unwittingly pressured by government agents into committing crimes that they were not previously disposed to commit. ${ }^{156}$ Some courts were troubled by the conduct of the government agents-one federal judge termed it "outrageous"157 — but all convictions were affirmed on appeal. ${ }^{158}$ The entrapment defense was rejected by the appellate courts that reviewed the convictions; the courts held that federal agents may lawfully "simulate the guarded conversation that would be expected of those proposing an unlawful venture. They need not say, 'Congressman, I have here a cash bribe to be exchanged for your corrupt promise to be influenced in your official action." 159

In Operation Greylord, dozens of FBI agents--all of whom were lawyers-posed as state prosecutors and defense attorneys in an undercover sting operation which netted over 60 bribery convictions of corrupt judges and lawyers. ${ }^{160}$ The FBI literally made up one hundred ersatz crimes that were used as bait to lure corrupt lawyers and judges. ${ }^{161}$ Significantly, the federal agents consummated their scams by giving false

155. See id; United.States. v. Williams, 705 F.2d 603 (2d Cir. 1983); United.States. v. Myers, 692 F.2d 823 (2d Cir. 1982); see also Wikipedia Entry on Abscam, http://en.wikipedia.org/wiki/ Abscam (last visited August 3, 2008).

156. See United States v. Kelly, 539 F. Supp. 363 (D.D.C. 1982), rev'd, 707 F.2d 1460 (D.C. Cir. 1983). Even those trial courts which initially dismissed Abscam indictments on grounds of government overreaching agreed in principle with the permissibility of undercover investigations under proper circumstances. For example, in Kelly, the trial judge, while dismissing the charges against Congressman Kelly, due to "outrageous" government conduct, acknowledged that "carefully devised and supervised covert investigations often are the only means of discovering breaches of the fundamental mandate of one's office." $539 \mathrm{~F}$. Supp. at 371.

157. Id. at 373 .

158. See Kelly, 707 F.2d 1460; Williams, 705 F.2d 603; Myers, 692 F.2d 823; United States v. Alexandro, 675 F.2d 34 (2d Cir. 1982); United States v. Jannotti, 673 F.2d 578 (3d Cir. 1982); see also Blecker, supra note 107 , at 964 .

159. Myers, 692 F.2d at 844.

160. See OfFICE OF INSPECTOR GENERAL, THE FEDERAL BUREAU OF INVESTIGATION'S COMPLIANCE WITH THE ATtORNEY GeNeRAL'S INVESTIGATIVE GuIDELINES (REDACTED), ch. 4 (September 2005), available at http://www.usdoj.gov/oig/special/0509/chapter4.htm.

161. As described by the Justice Department Office of the Inspector General:

FBI agents who were licensed attomeys assumed roles as county prosecutors and private practitioners. In addition, the FBI recruited a state prosecutor and a judge from southern Illinois who were temporally assigned to Cook County to deal with the backlog of cases there. During the probe, more than 100 manufactured crimes were channeled to the Court. Equipped with electronic surveillance devices, the undercover agents were able to record hundreds of incriminating conversations with judges and attorneys which revealed that judges routinely accepted bribes to dismiss cases and received kickbacks from attorneys for assigning cases to them. 
testimony about their fabricated cases. ${ }^{162}$ The court of appeals, in affirming the conviction of a corrupt judge, upheld the government's use of lies and deception. ${ }^{163}$

Perjury is a crime, and Murphy tells us that those who commit crimes themselves cannot prosecute others' crimes. But criminal proceedings are not designed to establish the relative equities among police and defendants. In many categories of cases it is necessary for the agents to commit acts that, standing by themselves, are criminal. ${ }^{164}$

Thus, the federal court in Operation Greylord-unlike the courts in $\mathrm{Ma}$ lone and Friedman - upheld the use of perjury to prosecute corruption in the legal system.

While, as is evident from the foregoing examples, government lawyers frequently supervise undercover investigations, it is less clear whether such conduct complies with the literal language of Model Rule 8.4. The focus of the courts generally has been on the overall legality of the government conduct and the applicability of the entrapment defense, not on the ethics of individual government attorneys. ${ }^{165}$ The ethical issues raised by lawyer involvement in undercover surveillance are further highlighted by the McDade Amendment, which commands federal prosecutors to comply with state ethics rules. ${ }^{166}$ Now, government lawyers engaged in nationwide investigations must comply with the ethics rules of each individual jurisdiction in which they operate, and in which they are licensed. ${ }^{167}$ Furthermore, most states follow ABA Model Rule 8.4 by explicitly forbidding lawyer conduct based on dishonesty, deceit or mis-

162. See United States v. Murphy, 768 F.2d 1518, 1528 (7th Cir. 1985).

163. Id. at 1541 . The conduct upheld by the federal courts in Operation Greylord is similar to the subomation of perjury which resulted in a public sanction for a state prosecutor in In re Friedman. In both instances, a prosecutor instructed a law enforcement agent to lie under oath in order to consummate a bribery prosecution.

164. Id. at 1528 .

165. See id.

166. Omnibus Consolidated and Emergency Supplemental Appropriations Act of 1999, Pub. L. No. 105-277, § 801 (1998) (codified in relevant part at 28 U.S.C. § 530B (2000)). See Zacharias \& Green, supra note 147, at 231. Zachiarias and Green criticize the McDade Amendment, which subjects federal prosecutors to state ethics regulations, for, among other things, subjecting federal prosecutors to a patchwork of potentially inconsistent state regulations. Id. These state ethics rules are not designed for federal prosecutors, who are generally held to a higher standard than state practitioners, and state rules could impose unnecessary burdens on federal law enforcement, which is already regulated by the federal courts and executive branch. See id.

167. This imposes an enormous responsibility on those attorneys who conduct an investigation in numerous jurisdictions. For example, the Abscam investigation involved conduct in many jurisdictions, including the incorporation of "Abdul Enterprises" in New York, meetings on a Florida yacht, meetings in Washington D.C., Virginia and New Jersey. See United States v. Kelly, 707 F.2d 1460, 1462-67 (D.C. Cir. 1983). 
representation. ${ }^{168}$ As a result, as one commentator has noted, " $[t]$ he current rules of professional conduct fail to recognize the expanded role played by the government attorney in the investigation of federal crimes and do not provide sufficient guidance for the government attorney's behavior." 169 The McDade amendment, along with the inconsistencies in the various approaches to the problem of deception in undercover investigations, complicates the lives of federal prosecutors.

A federal district court has analyzed the ethical issues raised in attorney supervision of undercover investigations. United States v. Parker arose from an undercover investigation of police officers for corruption and civil rights violations. ${ }^{170}$ The FBI set up an undercover sting operation, targeting the local police, in which federal agents and informants posing as drug dealers were extorted and robbed by the local police officers. ${ }^{171}$ The defendant police officers claimed that the investigating attorneys improperly employed deception, dishonesty and misrepresentation in violation of DR 1-102 of New York's Code of Professional Responsibility. ${ }^{172}$ In response, the district court advanced the questionable proposition that the Code's proscription on attorney deception did not apply to prosecutors: "Indeed, opinions of state and local bar associations hold DR 1-102(A)(4) does not apply to prosecuting attorneys who provide supervision and advice to undercover investigations." 173 The district court roundly rejected the challenge to undercover operations supervised by federal prosecutors:

Defendants' logic would, if accepted, mean that government attorneys could not supervise investigations involving undercover agents

168. See discussion infra Part V.

169. Roberta K. Flowers, A Code of Their Own: Updating the Ethics Codes to Include the NonAdversarial Roles of Federal Prosecutors, 37 B.C. L. REv. 923, 925-26 (1996).

170. 165 F. Supp. 2d 431, 476 (W.D.N.Y. 2001).

171. Id. at 440 .

172. They also argued that they were entrapped by government agents. See $i d$. at 476.

173. Id. (citations omitted). This aspect of the court's decision is actually mistaken, as it misreads two New York Ethics Opinions concerning the permissibility of surreptitious tape recording, neither of which carves out an explicit exception for prosecutors. See N.Y. City Law Ass'n, Formal Ethics Op. 696 (1993) (permitting surreptitious taping regardless of attorney status); N.Y. State Bar Ass'n, Formal Ethics Op. 515 (1979), available at http://www.nysba.org/AM/Template.cfm?Section=Ethics_Opinions\&CONTENTID $=5059 \&$ TEMPLATE $=/$ CM/ContentDisplay.cfm (holding that lawyer in criminal case, regardless of whether government or private, may secretly record telephone conversation with consent of one side). Thus, the court simply misread two local bar association ethics opinions. In addition, the district court overlooked the (admittedly confusing) decision of the Second Circuit Court of Appeals in United States v. Hammad, 858 F.2d 834 (2d Cir. 1988), which held that federal prosecutors must comply with the non-contact rule of New York Lawyer's Code DR 7-104. See Hammad, 858 F.2d 834. If the no contact rule does apply to undercover federal investigations, albeit honored in the breach, it would seem logical for the ban on deception in New York Lawyer's Code DR 1-102 to apply as well. 
and informants who cannot reveal their true identity and purpose to the targets of the investigation without thereby rendering the investigation futile and dangerous. There is no authority for such a conclusion. ${ }^{174}$

Thus, the district court held that government lawyers may ethically supervise undercover investigations involving deception. ${ }^{175}$

Even state ethics prosecutors have been known to resort to deception and trickery in their own investigations of attorney misconduct. The Minnesota Office of Lawyers Professional Responsibility (OLPR)-the Minnesota lawyer police-has, in the past, dispatched investigators to see if suspended or disbarred lawyers will take illicit bait in the form of prospective inquiring clients. ${ }^{176}$ According to William Werntz, former chief counsel to the Minnesota OLPR, a government investigator would telephone suspended or disbarred lawyers to inquire whether they were still practicing. ${ }^{177}$ While there was no outright lying by the investigator, who used her actual name, she nonetheless would not identify herself as a representative of the bar counsel. ${ }^{178}$ An illustrative example of the investigator's phone call would be something like this: "Hello, I'm Lynda Olson and I'm wondering whether Mr. Doe is available for representation in a family law matter." 179 In the event that the unsuspecting target took the bait and accepted the ersatz client, the suspended attorney would be prosecuted for unauthorized practice of law or contempt of court. ${ }^{180}$

At this time, particularly in light of the Colorado Supreme Court's decision in Pautler, ${ }^{181}$ there is no definitive national solution to the question of whether a government lawyer may ethically supervise a deceptive

174. United States v. Parker, 165 F. Supp. 2d 431, 476-77 (W.D.N.Y. 2001).

175. The court alternatively held that even if the prosecutors' conduct were to violate the Code, exclusion of the evidence is not required. See id.

176. See William Wernz, 'Pretexting,' Prevaricating and Getting the Facts, MINN. LAW., Oct. 30, 2006, available at http://www.minnlawyer.com/article.cfm?recid $=74661$.

177. Id. William Wernz left OLPR in approximately 1992. Id. at 1.

178. See id.

179. See id. According to Mr. Wernz, a former chief counsel to the Minnesota Office of Lawyers Professional Responsibility, the investigator would never actually lie to the lawyer, i.e., by assuming a fake identity or falsely pretending to be a client. She would rather say, truthfully, that she was "interested in finding out whether" the ineligible lawyer was willing to accept a new casea literally true proposition. The OLPR would allow the target of the sting to assume that the reason that the caller is "interested" is because of a desire for legal services-not a desire to prosecute. Telephone Interview with William Wernz, Former Chief Counsel, Minn. Office of Law. Prof'l Responsibility (October 10, 2007). Lynda Olson is not the name of an OLPR investigator.

180. The Minnesota Office of Lawyers Professional Responsibility advises that the procedures described in the Wernz article are not consistent with current OLPR practice or policy. E-mail from Minn. Office of Law. Prof'l Responsibility to Barry R. Temkin, Adjunct Professor of Law, New York Law School (2008) (on file with author).

181. See discussion supra Part III.B. 
investigation. Most state bars to have considered this issue-with the notable exception of Oregon ${ }^{182}$ - have carved out an exception for prosecutors who supervise undercover criminal investigations. ${ }^{183}$

\section{B. Testers in Civil Rights Cases}

Plaintiffs' civil rights lawyers have long used testers in order to build discrimination cases against employers or landlords, often supplying their testers with "elaborately falsified credentials." 184 Testers have traditionally been dispatched to gather evidence of racial steering and other discriminatory practices by which employers, landlords, sellers, or real estate agents falsely tell minority applicants that there are no vacancies or "steer" them to segregated housing. ${ }^{185}$ As the Supreme Court has explained, "'testers" are individuals who, without an intent to rent or purchase a home or apartment, pose as renters or purchasers for the purpose of collecting evidence of unlawful steering practices." 186 The use of undercover testers in discrimination cases has been approved by the courts:

This court and others have repeatedly approved and sanctioned the role of 'testers' in racial discrimination cases. It is frequently difficult to develop proof in discrimination cases and the evidence provided by testers is frequently valuable, if not indispensable. . . . $[W]$ e have long recognized that this requirement of deception was a relatively small price to pay to defeat racial discrimination. ${ }^{187}$

Most authorities have agreed that the use of deception by testers is "a reasonable way - in fact, a necessary way - to carry the burden of proving discrimination." 188 The goal of fighting racial discrimination is admirable. But does the lofty goal justify the use of deception by attorneys who guide and supervise testers?

Although several authorities acknowledge the prevalence of and need for discrimination testers, ${ }^{189}$ fewer authorities specifically consider

182. See discussion supra Part III.D.

183. As discussed infra Part V, prosecutors may supervise undercover criminal investigations in Utah, Oregon, and Florida.

184. Isbell \& Salvi, supra note 22, at 793.

185. See generally Havens Reality Corp. v. Coleman, 455 U.S. 363, 373 (1981).

186. Id. at 373. The primary issue in Havens was whether black and white testers had standing to sue a discriminating landlord under the Fair Housing Act of 1968. The landlord steered black testers to one apartment complex, and white testers to another. There was no discussion of the ethics of the attomeys supervising the investigation.

187. Richardson v. Howard, 712 F.2d 319, 321 (7th Cir. 1983).

188. Freedman, supra note 65, at 780. Accord Apple Corps Ltd. v. Int'l Collectors Soc'y, 15 F. Supp. $2 d 456$ (D.N.J. 1998); Gidatex v. Campaniello Imports, Ltd., 82 F. Supp. $2 d 119$ (S.D.N.Y. 1999).

189. See Havens Realty Corp., 455 U.S. at 373; Richardson, 712 F.2d at 321. 
the ethics of attorneys who supervise testers. As mentioned above, Isbell and Salvi articulated a rationale for approving the ethics of lawyers supervising discrimination testers, arguing that "the scales of social policy tip markedly in favor of the use of undercover investigators and discrimination testers, despite the deceptions necessarily entailed."190 The ban on deception in Model Rule 8.4 should be narrowly limited to those misrepresentations that "would be considered of such gravity as to raise questions as to a person's fitness to be a lawyer."191 Without defining the outer boundaries of such conduct, Isbell and Salvi argue that the use of discrimination testers, solely to gather evidence, does not violate Rule 8.4 .

There is a dearth of judicial authority on the ethics of lawyers who supervise testers. One trial court recently considered the surreptitious tape recording of unsuspecting adversaries in a discrimination case and held that the surreptitious tape recording, and subsequent press release, of discriminatory evidence was ethically justified both by the societal interest in combating discrimination and by the need for the deception in order to capture otherwise fleeing evidence. ${ }^{192}$ In addition, several state ethics committees have approved the practice in discrimination cases. ${ }^{193}$ The issue has not, however, been squarely addressed by the courts.

\section{Intellectual Property Cases}

Undercover investigations are often used in trademark and unfair competition cases. ${ }^{194}$ A primary rationale behind the intellectual property exception is that deception is often the only way to police counter-

190. Isbell \& Salvi, supra note 22 , at 804 . This influential article opened the door for many courts and bar associations to approve testers in discrimination cases. However, some of Isbell and Salvi's arguments have proved to be strained, including the claim that a lawyer posing as an investigator is not acting "in the course of representing a client" within the meaning of Model Rule 4.1. Id. at 816-17. While it may or may not be correct, it misses the point, since most sting operations involve undercover investigators supervised by lawyers. As a matter of common sense, the civil rights lawyer who tells a tester to assume a fake identity is doing so on behalf of a client, in the lawyer's representational capacity. Moreover, the test of whether a lawyer acts in a representative capacity depends on a number of factors, including an agreement with the client to provide legal services, a retainer agreement, fee arrangement, past relationships with the client, etc. See Barry R. Temkin, Is There a Tort of Negligent Referral?, 17 TOURO L. REV. 639 (2001). In any event the whole point of Isbell and Salvi's article is to create a rationale for lawyers, acting in their representative capacity, who supervise investigators. Thus the argument that Model Rule 4.1 does not apply to lawyers qua investigators does not advance the overall argument.

191. Isbell \& Salvi, supra note 22, at 817.

192. See Mena v. Key Food Stores Co-Operative, 758 N.Y.S.2d 246 (Sup. Ct. Kings County 2003)

193. See New York County Lawyers Ass'n Comm. on Prof'l Ethics, Formal Op. No. 737 (2007), available at http://www.nycla.org/ethicsopinions. [hereinafter N.Y. County Ethics Op. 737].

194. See, e.g., Apple Corps Ltd. v. Int'l Collectors Soc'y, 15 F. Supp. 2d 456 (D.N.J. 1998) 
feiting and trademark infringement. ${ }^{195}$ A lawyer or investigator who openly identifies herself as an agent of the trademark owner is unlikely to uncover evidence of infringing conduct. In addition, the courts have discussed the public policy of protecting intellectual property rights.

The Beatles, Paul McCartney, Yoko Ono, and the estate of the late John Lennon served as the background for an examination of the ethics of investigative techniques in Apple Corps Ltd. v. International Collectors Society. ${ }^{196}$ Apple Corps agreed with defendant International Collectors Society (ICS) to limit distribution of commemorative postage stamps featuring images of the Beatles to members of a specific fan club. ${ }^{197}$ Suspecting non-compliance with their agreement, counsel for the plaintiff telephoned ICS's public, toll-free telephone number and inquired as to the availability of the stamps. ${ }^{198}$ The lawyer did not identify herself as counsel of the estate, and she used her married name to avoid detection. ${ }^{199}$ Although the lawyer was not a member of the fan club and not eligible to receive the stamps, the defendant, ICS, complied with her request. $^{200}$ Acting at the request of counsel for the plaintiff, other callersincluding a legal secretary, investigators, and an attorney's husband-telephoned the defendants and ordered stamps that should have been available only to fan club members under the consent agreement. ${ }^{201}$

The district court found that the sale of Beatles stamps to nonmembers violated the consent decree and further found that the conduct of the plaintiff's counsel did not violate ethical restrictions on contact with represented parties under New Jersey Rule of Professional Conduct (RPC) 4.2 or the proscription on deceit under Rule $8.4(\mathrm{c}){ }^{202}$ Rather, the court held that "RPC 4.2 cannot apply where lawyers and/or their investigators, seeking to learn about current corporate misconduct, act as members of the general public to engage in ordinary business transactions with low-level employees of a represented corporation."203

The court similarly found that Apple's attorneys did not engage in "dishonesty, fraud, deceit or misrepresentation" because New Jersey Rule 8.4 "does not apply to misrepresentations solely as to identity or

195. See, e.g., Gidatex v. Camapniello Imports, Ltd., 82 F. Supp. 2d 119, 124 (S.D.N.Y. 1999) (noting that it is difficult if not impossible to prove "palming off" theory without resort to deception).

196. 15 F. Supp. $2 d 456$ (D.N.J. 1998).

197. Id. at 468.

198. Id. at 462

199. Id. at 462 . The attorney practiced under her married name.

200. See id.

201. See id. at $462-63$

202. See Apple Corps Ltd. v. Int'l Collectors Soc'y, 15 F. Supp. 2d 456, $473-77$ (D.N.J. 1998).

203. See id. at 474-75. 
purpose and solely for evidence-gathering purposes."204 Relying in part on the declaration of plaintiffs' expert witness, Professor Bruce Green, the court observed that " $[t]$ he prevailing understanding in the legal profession is that a public or private lawyer's use of an undercover investigator to detect ongoing violations of the law is not ethically proscribed, especially where it would be difficult to discover the violations by other means."205 The deception proscribed by Rule 8.4 is limited to "grave misconduct that would not only be generally reproved if committed by anyone, whether lawyer or nonlawyer, but would be considered of such gravity as to raise questions as to a person's fitness to be a lawyer."206 Testers and investigators, on the other hand, do not engage in grave dishonesty but instead "do no more than conceal their identity or purpose to the extent necessary to gather evidence."207 Thus deception, when limited to purpose and identity, is not unethical when necessary to investigate ongoing unlawful conduct. Other intellectual property cases have similarly held that undercover deception is ethically permissible. ${ }^{208}$

While some lower courts have carved out limited exceptions to the lawyer honesty rule, not all authorities are in agreement, as we will see infra in Part V. Some jurisdictions have sought to carve out exceptions permitting deception by law enforcement officers acting in their capacity as such, while other jurisdictions have attempted to adopt the Isbell and Salvi gloss on Rule 8.4, which narrows the rule to proscribe only deceptive conduct that reflects adversely on an attorney's fitness to practice law.

\section{STATE ATTEMPTS TO RECONCILE THE CONFLICT BY STATUS-BASED DISTINCTIONS}

As discussed, the tension between the literal language of the ABA Model Rules and the need for undercover investigations, particularly in criminal cases, has not been susceptible to easy resolution. As we have seen, the Oregon response to In re Gatti was to amend the state's ethics rules to permit lawyers, regardless of their public/private status and without respect to the subject matter of the underlying claim, to indirectly supervise and counsel clients about deceptive undercover investi-

204. Id. at 475 .

205. Id.

206. Id. at 476 (quoting Isbell \& Salvi, supra note 22, at 817).

207. Id.

208. See, e.g., Gidatex v. Camapniello Imports, Ltd., 82 F. Supp. 2d 119, 122 (S.D.N.Y. 1999) ("The presence of investigators posing as interior decorators did not cause the sales clerks to make any statements they otherwise would not have made. There is no evidence to indicate that the sales clerks were tricked or duped by the investigators' simple questions such as 'is the quality the same?' or 'so there is no place to get their furniture?"'). 
gations. ${ }^{209}$ Oregon has in effect eliminated status-based distinctions. But no other state has been prepared to go that far. The results, as discussed below, have been strained and inconsistent.

\section{A. The Florida Approach: Status-Based Exception}

The Florida Rules of Professional Conduct explicitly exempt law enforcement officers and prosecutors from the general ban on deception. $^{210}$ The 2006 amendment ${ }^{211}$ to the Florida rules provide that a lawyer may not

[E]ngage in conduct involving dishonesty, fraud, deceit, or misrepresentation, except that it shall not be professional misconduct for a lawyer for a criminal law enforcement agency or regulatory agency to advise others about or to supervise another in an undercover investigation, unless prohibited by law or rule, and it shall not be professional misconduct for a lawyer employed in a capacity other than as a lawyer by a criminal law enforcement agency or regulatory agency to participate in an undercover investigation, unless prohibited by law or rule. ${ }^{212}$

Thus, prosecutors may supervise or give advice about an undercover investigation. ${ }^{213}$ The rule is ambiguously written, but seems to suggest that a government lawyer employed in a non-representational capacity may participate in an undercover investigation. ${ }^{214}$

The commentary to the Florida rule does little to explain its rationale but does appear to reiterate that only government lawyers may supervise undercover investigations: "Subdivision (c) recognizes instances where lawyers in criminal law enforcement agencies or regulatory agencies advise others about or supervise others in undercover investigations,

209. Oregon's amended rule 8.4, as discussed infra, states that covert activity is permitted only where there is a reasonable basis for the attorney to believe that unlawful conduct is afoot. OR. RULES OF PROF'L CONDUCT R. 8.4 (2008).

210. See FLA. RULES OF PROF'L CONDUCT R. 4-8.4(c) (2008).

211. See sunEthics.com, Florida New Archive - Lawyer Ethics, Rules and Opinions, http:/sun ethics.com/le-rulesops.htm (last visited August 3, 2008).

212. FLA. RULES OF PROF'L CONDUCT R. 4-8.4(c) (emphasis added).

213. The commentary to the Florida Rule suggests that only government lawyers may supervise undercover investigations. See FLA. RULES OF PROF'L CONDUCT R. 4-8.4 cmt.

214. Florida Rule 4-8.4(c) as written could mean one of two things. It could mean that "a lawyer employed . . by a criminal law enforcement agency" in a capacity "other than a lawyer " may directly participate in an undercover sting. I.e., an FBI agent who happens to be a lawyer may ethically serve as an undercover agent. The other interpretation is to permit deception by any lawyer "employed in a capacity other than as a lawyer by a criminal law enforcement agency or regulatory agency"-i.e., any lawyer in private practice may directly participate in an undercover sting. Given the context and the interpretation of similar rules in other states, including Virginia, the former interpretation makes more sense. It would seem anomalous to accord more leeway in Florida to lawyers in private practice than to government prosecutors. 
and provides an exception to allow the activity without the lawyer engaging in professional misconduct. The exception acknowledges current, acceptable practice of these agencies." 215

\section{B. Utah State Bar: Prosecutors May Supervise Undercover Investigations}

Utah has attempted to carve out a status-based exception for government attorneys who supervise undercover criminal investigations. Unlike Florida, however, Utah has done so by an ethics opinion rather than formal rule change. ${ }^{216}$ The Utah Bar reasons that some level of deception is necessary for law enforcement agents to infiltrate sophisticated criminal enterprises. ${ }^{217}$ Although there is some deception involved in running an undercover law-enforcement sting operation, Utah Ethics Rule 8.4 was not intended to "prohibit prosecutors or other government lawyers from participating in lawful undercover investigations." $218 \mathrm{Ra}-$ ther, the Utah ethics rule "was intended to make subject to professional discipline only illegal conduct by a lawyer that brings into question the lawyer's fitness to practice law. It was not intended to prevent state or federal prosecutors or other government lawyers from taking part in lawful, undercover investigations." ${ }^{219}$ Thus, Utah has chosen to interpret its ethics rules to imply a status-based law enforcement exception permitting prosecutors-and no one else-to supervise deceptive investigations.

\section{District of Columbia: The CIA Agent Opinion}

The District of Columbia Bar Association considered misrepresentations as to identity by federal agents and intelligence operatives who happen to be licensed as attorneys, but who lie in their nonrepresentational capacities. ${ }^{220}$ The D.C. Bar Association opinion concluded that FBI agents and CIA operatives who lie in their field jobs, and who are not engaged in the practice of law, do not violate D.C. Rule

215. Fla. Rules OF Prof'L CONDUCT R. 4-8.4 cmt.; sunEthics.com, Florida New Archive Lawyer Ethics, Rules and Opinions, http://sunethics.com/le-rulesops.htm (last visited August 3, 2008).

216. See Utah State Bar Ethics Advisory Op. Comm., Formal Op. $02-05$ (2002), available at http://www.utahbar.org/rules_ops_pols/ethics_opinions/op_02_05.html\#f18 [hereinafter Utah Ethics Op.].

217. Id. at 1-2 (quoting Select Committee to Study Undercover Activities of Components of the Department of Justice, 97th Cong. 2d Sess. 11 (1982)).

218. Utah Ethics Op., supra note 216, 99.

219. Id. ๆ 10.

220. See Dist. of Columbia Bar, Formal Op. 323, at 2 (2004), available at http://www.dcbar. org/for_lawyers/ethics/legal_ethics/opinions/opinion323.cfm [hereinafter D.C. Ethics Op.]. 
8.4. ${ }^{221}$ The D.C. ethics committee reasoned that the rule's proscription on "fraud, deceit, or misrepresentation" does not apply to all lying. ${ }^{222}$ Rather, the language applies "only to conduct that calls into question a lawyer's suitability to practice law." 223 Covert surveillance work is dangerous. As the committee explained, "[s]ome activities conducted on behalf of the United States necessarily involve circumstances where disclosure of one's identity or purpose would be inappropriate-and, indeed, potentially dangerous." ${ }^{224}$ As the D.C. ethics committee wrote: "An attorney's professional competence and ability are not called into question by service in our intelligence or national security agencies in conformance with legal authorization, nor is it called into question by the use of effective covert means to achieve legitimate national security goals." ${ }^{225}$ Thus, D.C. Rule 8.4 does not prevent a federal government employee from use of a concealed identity. ${ }^{226}$ This opinion does not, by its terms, apply to U.S. attorneys or other government lawyers who represent clients-including the government-in court. Similarly, it does not, by its terms, seem to apply to state or local undercover agents.

\section{Virginia: Adopting the Isbell and Salvi Gloss}

Recognizing the tension between the literal language of its version of Rule 8.4, and the actual practice on the ground by federal law enforcement agencies, the Virginia State Bar Association recommended an amendment to the rule. ${ }^{227}$ As amended, Virginia Rule $8.4(\mathrm{c})$ currently provides that "it is professional misconduct for a lawyer to . . . engage in conduct involving dishonesty, fraud, deceit, or misrepresentation which reflects adversely on the lawyer's fitness to practice law." 228 The italicized language was added in 2003, following Pautler and Gatti. Virginia lawyers now are permitted to deceive as long as their deception does not adversely reflect on their fitness to practice law. On its face, the amended Virginia rule makes no status-based distinctions, as, for example, between government and non-government lawyers.

However, a 2004 Virginia Legal Ethics Opinion took a status-based approach to the newly amended Virginia Rule 8.4 by considering and

221. Id.

222. Id.

223. Id.

224. Id. at 3.

225. Id. at 2.

226. Id. at 2 (citing Apple Corps Ltd. v. Int'l Collectors Soc'y, 15 F. Supp. 2d 456, 476 (D.N.J. 1998)).

227. See Va. Continuing Legal Educ. Comm., Legal Ethics Op. 1765 (2003), available at http://www.vacle.org/opinions/1765.htm [hereinafter Va. Ethics Op. 1765].

228. See id. (quoting VA. RULES OF PROF'L CONDUCT R. 8.4.4(c)) (emphasis added). 
approving deception by law enforcement agents acting as field agents. ${ }^{229}$ The Virginia opinion does not explicitly consider the case of government lawyers-such as assistant United States attorneys-acting in their "representational capacities" on behalf of clients. According to the Virginia ethics committee:

[W] hen an attorney employed by the federal government uses lawful methods, such as the use of "alias identities" and non-consensual tape-recording, as part of his intelligence or covert activities, those methods cannot be seen as reflecting adversely on his fitness to practice law; therefore, such conduct will not violate the prohibition in Rule $8.4(\mathrm{c})$. $^{230}$

Left for another day are the questions of whether the new language permits the use of aliases by state prosecutors, by federal prosecutors who supervise investigations, by defense counsel, by civil practitioners, and so on.

\section{E. The Iowa Approach: Finesse with a Comment}

Yet another approach is illustrated by Iowa, in which the relevant ethics rule closely tracks ABA Model Rule 8.4 in broadly proscribing deceit, fraud and misrepresentation, yet addresses the problem of undercover investigations by means of a comment. ${ }^{231}$ According to the Iowa commentary:

It is not professional misconduct for a lawyer to advise clients or others about or to supervise or participate in lawful covert activity in the investigation of violations of civil or criminal law or constitutional rights or in lawful intelligence-gathering activity, provided the lawyer's conduct is otherwise in compliance with these rules. "Covert activity" means an effort to obtain information on unlawful activity through the use of misrepresentations or other subterfuge. Covert activity may be commenced by a lawyer or involve a lawyer as an advisor or supervisor only when the lawyer in good faith believes there is a reasonable possibility that unlawful activity has taken place, is taking place, or will take place in the foreseeable future. Likewise, a government lawyer who supervises or participates in a lawful covert operation which involves misrepresentation or deceit for the purpose of gathering relevant information, such as law

229. See Va. Ethics Op. 1756, supra note 227.

230. See id.

231. See Iowa Rules of PROF'L CONDUCT R. 8.4 cmt. 6 (2008). 
enforcement investigation of suspected illegal activity or an intelligence-gathering activity, does not, without more, violate this rule. ${ }^{232}$

According to Professor Gregory Sisk, the Iowa comment was passed by the state supreme court in the wake of the Gatti ruling in Oregon and the Apple Corps ruling in New Jersey, in order to ensure that legitimate undercover investigations could be pursued by law enforcement agents and by private attorneys investigating violations of law. ${ }^{233}$ The Iowa exception follows the amendments to the Oregon code and applies to investigations of violations of civil law and constitutional rights, as well as to criminal law. ${ }^{234}$ Note that the Iowa rule, unlike Florida, is not limited to law enforcement officers.

\section{F. A Mixed Status and Conduct Based Approach: New York County Lawyers Association}

In 2007, the New York County Lawyers' Association Professional Ethics Committee (the "NYCLA committee") issued NYCLA Opinion 737, which analyzed the deception issue in terms of both status and conduct. $^{235}$ In the first instance, the NYCLA committee wrote that deception, fraud and misrepresentation are never permitted; rather lawyers may, in certain circumstances, engage in "dissemblance," which the committee limited to "misstatements as to identity and purpose made solely for gathering evidence." 236 The opinion further limited its scope to civil matters only, and did not opine on criminal cases, although it approvingly cited United States v. Parker, which permits deception in undercover investigations supervised by federal prosecutors. ${ }^{237}$ The NYCLA committee concluded that, in civil cases, dissemblance, limited to identity and purpose, is ethically permissible where:

(i) either (a) the investigation is of a violation of civil rights or intellectual property rights and the lawyer believes in good faith that such violation is taking place or will take place imminently or (b) the dissemblance is expressly authorized by law; and

232. Id.

233. 16 IOWA PRACTICE SERIES $\$ 12: 4$ (a) (2008).

234. See Iowa Rules of Prof'L Conduct R. $8.4 \mathrm{cmt}$. 6; 16 Iowa Practice Series $\S$ 12:4(e).

235. N.Y. County Ethics Op. 737, supra note 193. The author is Chair of the New York County Lawyers Association Professional Ethics Committee ("NYCLA") and participated in the drafting of NYCLA Ethics Opinion No. 737.

236. Id. at 2. Black's Law Dictionary defines "dissemble" as: "To give a false impression about (something); to cover up (something) by deception . . . " BLACK'S LAW DICTIONARY 506 (8th ed. 2004). Thus, the definition of dissemblance contains an element of deception.

237. See United States v. Parker, 165 F. Supp. 2d 431, 478 (W.D.N.Y. 2001). 
(ii) the evidence sought is not reasonably available through other lawful means; and

(iii) the lawyer's conduct and the investigators' conduct that the lawyer is supervising do not otherwise violate the Code . . . ${ }^{238}$

Thus, the NYCLA opinion limits its reach to misrepresentions of identity and purpose in two areas of the law: intellectual property and civil rights. The deception must be narrow and is not permissible where there are alternative means (such as discovery) to obtain the same information. ${ }^{239}$ Nevertheless, the NYCLA approach, as explained below, maintains status-based distinctions and should thereby not serve as a template for a nationwide solution to the lawyer honesty problem. Moreover, the NYCLA opinion sidesteps the entire criminal prosecution issue. ${ }^{240}$

In sum, Oregon and Virginia have explicitly modified their ethics rules to permit deception that does not adversely reflect upon the lawyer's fitness to practice law. ${ }^{241}$ Other states permit undercover investigations supervised by government attorneys, either by explicit amendment to the state ethics rules (Florida), ${ }^{242}$ by judicial interpretation (New York), ${ }^{243}$ or by ethics committee (D.C.). ${ }^{244}$ And Iowa permits lawyer involvement in undercover investigations, regardless of the underlying subject matter, based on a comment to the ethics rule. ${ }^{245}$

\section{STAtUS-BASEd Distinctions ARE TOO SUbJective AND VALUE-LADEN}

\section{A. Subject Matter and Conduct Axes}

Analysis of the ethics of undercover investigations has historically been driven by and followed societal values, especially in the instances of discrimination testers and law enforcement. Permitting some dissemblance by investigators has served overall social goals, namely remedying racial discrimination and prosecuting crime. The relatively recent growth of intellectual property testers in undercover investigations has opened a panoply of possibilities. The question arises whether subterfuge should be permitted for additional subject areas of the law, or

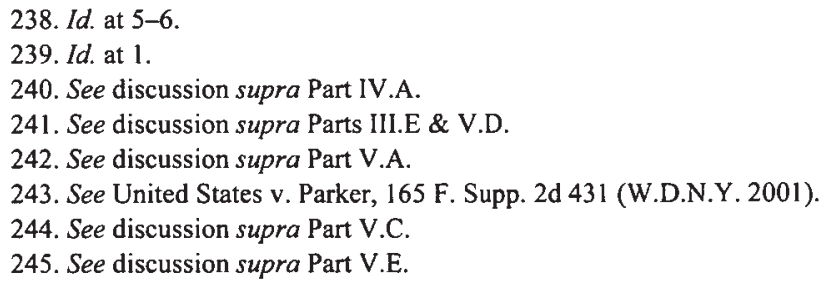


whether investigative deceit should be limited to the three subject areas outlined above, e.g., criminal, trademark and civil rights. A related question is whether the validity of the lawyer's conduct depends on the identity of the client, e.g., whether government lawyers should be given more leeway than private practitioners. Finally, we can ask whether the deception should be permitted only by lawyers representing claimants/plaintiffs, or whether the doors should be opened to defense attorneys as well.

To answer these and related questions, the courts and commentators have considered a number of factors, both explicitly and implicitly. On one hand, the courts and commentators have considered the nature of the underlying case (e.g,. criminal or trademark), the status of the actor (public or private), and the literal language of the Model Rules. ${ }^{246}$ Other authorities have focused on the nature of the attorney and investigator conduct (e.g., how egregious was the deception), the level of necessity for the particular conduct, whether there was a violation of substantive ethics rules, whether the attorney ratified the errant conduct of a rogue investigator, etc. ${ }^{247}$ And, of course, other authorities have addressed a combination of different factors. ${ }^{248}$

For the sake of this Article, these myriad factors can be analyzed along two axes, status-based and conduct-based. The factors related to the status-based axis pertain to both the subject matter of the case and the status of the attorney. The conduct-based axis focuses on the conduct of the attorney and investigator, as the attorney's agent. These factors include the following: the extent of the misrepresentation; whether the deceit is direct or indirect; whether the deceit was necessary; whether alternative methods of obtaining the same evidence exist; and whether the questioned conduct violates another ethics rule or principle of substantive law, most notably the "no contact rule" of Model Rule 4.2. Courts and commentators have often combined various factors in analyzing deception cases. ${ }^{249}$ In practice, conduct-axis factors have been driven by, and followed from, subject-matter factors. We will next test the parameters of the problem by use of a number of hypotheticals.

246. See, e.g., Parker, 165 F. Supp. at 431 (criminal investigation); Apple Corps Ltd. v. Int'l Collectors Soc'y, 15 F. Supp. 2d 456 (D.N.J. 1998) (intellectual property case); D.C. Ethics Op., supra note 220 (federal intelligence or national security agent who is lawyer may use deceit in furtherance of "legitimate national security goals").

247. See N.Y. County Ethics Op. 737, supra note 193.

248. In re Pautler, 47 P.3d 1175 (Colo. 2002) (en banc); N.Y. County Ethics Op. 737, supra note 193.

249. See, e.g., N.Y. County Ethics Op. 737, supra note 193. 


\section{B. The Slippery Slope Problem with Status-Based Distinctions: Hypothetical Examples}

The judicial opinions and scholarly articles on deception in investigations tend to emphasize the importance of enforcing federal civil rights laws, fighting housing discrimination, and enforcing trademark and copyright laws. ${ }^{250}$ The question arises whether the expansion of the law should stop there, or whether, on the other hand, there are other emerging areas of the law whose underlying values justify the use of deception. It may be difficult to engage in a ranking of values in order to determine which societal values are so great as to necessitate or tolerate deception, and which are not. Most of the commentators to weigh in on this topic seem to broadly agree that rectifying centuries of racial prejudice justifies the use of deception by testers. ${ }^{251}$ But what about enforcing the nation's intellectual property laws: Are these more important than protecting life and limb? In Pautler, the court held that any use of deception by an attorney was unacceptable, and publicly sanctioned a prosecutor who lied about his identity in order to secure the surrender of a multiple axemurderer. ${ }^{252}$ Arguably, the prosecutor's deception in Pautler saved human lives by obtaining the surrender of a rampaging murderer. Does it make sense to justify the deception as to identity in Gitatex and Apple Corps, which protected the property rights of wealthy corporations, but not the lying in Pautler, which may have actually saved lives?

And while testers have been socially useful in remedying discrimination, there are many zealous lawyers who practice in other areas of the law who undoubtedly, sincerely believe that other causes for other clients are equally deserving and useful. Environmental lawyers may seek to use undercover stings to combat toxic dumping; labor lawyers may seek to infiltrate unsafe factories; and insurance lawyers may seek to unmask insurance fraud and personal injury malingerers. ${ }^{253}$ Commercial lawyers employ undercover investigations in franchise, royalty, and other financial disputes. ${ }^{254}$ Any debate about the social value of these and other

250. See, e.g., Isbell \& Salvi, supra note 22; United States v. Parker, 165 F. Supp. 2d 431 (W.D.N.Y. 2001) (criminal investigation); Apple Corps Ltd. v. Int'l Collectors Soc'y, 15 F. Supp. $2 d$ 456 (D.N.J. 1998) (intellectual property case); D.C. Ethics Op., supra note 220 (federal intelligence or national security agent who is lawyer may use deceit in furtherance of "legitimate national security goals")

251. Isbell \& Salvi, supra note 22; Freedman, supra note 65 , at 780.

252. Pautler, 47 P.3d at 1176.

253. See, e.g., Stagg v. New York City Health \& Hospitals Corp., 162 A.D.2d 595 (N.Y. App. Div. 1990) (undercover investigator interviewed allegedly malingering plaintiff in personal injury case).

254. See, e.g., Midwest Motor Sports v. Arctic Cat Sales, Inc., 347 F. $3 \mathrm{~d} 693$ (8th Cir. 2003) (investigator interviewed adverse party in franchise dispute). 
substantive areas of the law is inherently subjective and could vary among different areas of the country, and among persons holding different political beliefs, and different social values. Going forward, it is not useful for courts and ethicists to engage in a subjective ranking of these subject-area factors.

We will turn now to a number of hypothetical examples that serve to illustrate the limitations of and inconsistencies in existing precedents.

Hypothetical 1: Consider the example of a lawyer who wishes to investigate an imminent environmental hazard, a toxic waste dump near a residential neighborhood, or a potentially contaminated drinking water supply. The lawyer represents a homeowner's association or an environmental group and wishes to obtain information about the pollution from a local manufacturing concern that is suspected of causing the dangerous condition. There is no problem under the no-contact rule, the case is not in litigation, and the lawyer wishes to make a routine inquiry of a low-level clerical employee. May that lawyer directly contact the alleged polluter under an assumed identity? Is it different if the lawyer proceeds indirectly, through an investigator?

Hypothetical 2: A lawyer for a labor union hires an investigator to pose as an employee at a factory suspected of violating OSHA regulations. The manufacturer is suspected of removing safety guards on power saws and pressuring workers to curtail safety procedures.

Hypothetical 3: A government lawyer sends an undercover investigator into a prison under an assumed identity in order to investigate and infiltrate a violent gang. The investigator wears a recording device and transmits information to the lawyer, who advises the investigator whom to interview, what questions to ask, and what types of information to obtain. The targets of the investigation are not represented by counsel.

Hypothetical 3-A: A criminal defense lawyer is searching for an exculpatory witness in a capital case. The missing witness has a criminal record, is a possible suspect in an unrelated investigation, and is in hiding. The lawyer sends an investigator to pose as a gang member under an assumed identity in order to win the confidence and cooperation of the witness.

Hypothetical 4: A defense lawyer in a personal injury action represents a doctor whose alleged negligence incapacitated the plaintiff, who claims a permanent disability from work. Learning that the plaintiff has opened a cash retail business, the lawyer dispatches an investigator to pose as a customer and surreptitiously tape record the allegedly incapacitated plaintiff. 


\section{Analysis of Hypotheticals under Existing Law}

Each of these hypothetical examples presents persuasive grounds for permitting the use of deception, at least indirectly. However, under traditional legal principles, only Hypothetical 3, involving an undercover criminal investigation, is likely to be considered ethically permissible in most jurisdictions. ${ }^{255}$ The other examples, including the environmental case (Hypothetical 1) and OSHA investigation (Hypothetical 2), present important societal values that are no less significant than the civil rights and intellectual property cases in which deception has been endorsed by some authorities. ${ }^{256}$ However, there is no clear authority permitting the use of deception under these two hypotheticals.

Moreover, under existing law, it appears that the prosecutor in $\mathrm{Hy}$ pothetical 3 may ethically use an undercover investigator to gather inculpatory evidence of a crime, ${ }^{257}$ but the defense attorney in hypothetical $3 \mathrm{~A}$ may not use deception to gather exculpatory evidence in the same case. $^{258}$ In that hypothetical, the prosecutor would be permitted to supervise an undercover investigation in Florida, Utah, and possibly the District of Columbia, but the defense attorney would not. ${ }^{259}$ In Oregon and Iowa, the defense attorney and prosecutor alike would be able to supervise such an investigation only in the event of a likely violation of civil or criminal law. Because the prosecutor is investigating a crime under the terms of the hypothetical, this would be ethically permissible in Oregon and Iowa. But the defense attorney is merely trying to establish the existence of a reasonable doubt as to the client's guilt. Unless the defense attorney has reason to suspect and investigate a crime-such as grand jury perjury or obstruction of justice by a government witnesssuch an investigation could be unethical, even under Oregon law, which has otherwise eliminated status-based distinctions. ${ }^{260}$

To illustrate the problem further, consider the following additional hypothetical example. Assume that an assistant United States attorney (AUSA) is investigating the theft of a $\$ 500$ welfare check, a federal misdemeanor. In an unrelated case pending in the same jurisdiction, a public defender is representing a suspect accused of a capital crime. Under existing law in most jurisdictions, including Florida and even Oregon, the

255. See discussion supra Part IV.A.

256. See discussion supra Part IV.B-C.

257. See discussion supra Part IV.A.

258. Id.

259. See discussion supra Part IV.A-C,

260. See Or. Ethics Op., supra note 135 (2005) (stating that it must be unlawful conduct to justify use of deceit in an investigation). Jesse W. Barton has argued that permitting deception by prosecutors but not defense counsel could give rise to constitutional problems. See Barton, supra note 126 . 
AUSA can ethically use undercover investigators to prosecute a misdemeanor check theft, but the defense attorney may not ethically use the same techniques to defend his client in a death penalty case. ${ }^{261}$

This is a questionable result. Our adversary system is replete with safeguards that reflect the value of protecting individual rights and preventing the conviction of an innocent suspect. ${ }^{262}$ Accordingly, it seems anomalous to force a defense attorney to risk professional discipline in order to direct the kind of investigation that would be considered ethically acceptable if done by a prosecutor in the same case, or in a case with much lower stakes. ${ }^{263}$ While criminal prosecutors may well have additional weapons in their arsenals that are not available to criminal defense lawyers, ${ }^{264}$ deceit should not necessarily be one of them. ${ }^{265}$

Some commentators have argued that prosecutors in general, and federal prosecutors in particular, are unique in their jurisdictional and ethical obligations, ${ }^{266}$ such that they already receive and should continue

261. See discussion supra Part IV.A.

262. Blackstone wrote that "it is better that 10 guilty persons escape, than that one innocent suffer." Alan Vinegrad \& Douglas Bloom, Compensating the Wrongly Convicted, N.Y.L.J., Oct. 12, 2007, at 3 (quoting WILLIAM BLACKSTONE, 4 COMMENTARIES *358).

263. One Oregon criminal defense lawyer has even claimed that permitting government lawyers, but not the defense, to supervise undercover investigations, would be so unfair as to raise constitutional problems:

A criminal prosecutor could ground a prosecution on evidence obtained through covert activity, even though the defendant's lawyer was legally prohibited from using covert activity to disprove the prosecution evidence (or even to prove his client's innocence). This one-way exemption from the ban on dishonest evidence gathering could violate due process.

Barton, supra note 126. In Wardius v. Oregon, the Supreme Court held that it is a violation of due process to require a criminal defendant, but not the government, to give pretrial discovery of its witnesses. 412 U.S. 470, 475 (1973). The Court held: "The State may not insist that trials be run as a 'search for truth' so far as defense witnesses are concerned, while maintaining 'poker game' secrecy for its own witnesses." Id. In that case, an Oregon statute required the defense, but not the prosecution, to reveal its witnesses prior to trial. Id. at 471 . It is one thing to say that defendants are entitled to reciprocal discovery, and quite another thing altogether-and an expansion of the law-to say that the Constitution requires a leveling of the playing field in terms of permitting access to undercover investigations.

264. The Supreme Court has noted: "Prosecutors 'have available a terrible array of coercive methods to obtain information,' such as 'police investigation and interrogation, warrants, informers and agents whose activities are immunized, authorized wiretapping, civil investigatory demands [and] enhanced subpoena power."' Young v. United States, 481 U.S. 787, 811 (1987) (quoting C. WOLFRAM, MODERN LEGAL ETHICS 460 (1986)).

265. Hypothetical 4 is not clearly permissible under existing law, and raises concerns due to the investigator's direct contact with the target in violation of the no contact provisions of Model Rule 4.2.

266. Fred C. Zacharias and Bruce A. Green have argued (in general) that federal prosecutors are ethically unique in that they have a nationwide mandate, report to a single executive branch department, and are already subject to multiple layers of regulation by the executive branch and federal courts. See generally Zacharias \& Green, supra note 147. Federal prosecutors are responsible to the DOJ Office of Professional Responsibility, as well as their own licensing jurisdiction. See 
to receive special consideration as to whether they should be subject to a patchwork of state and federal ethics rules. ${ }^{267}$ Perhaps it is noteworthy in this regard that Pautler, Friedman, and Malone were all local or state prosecutors. ${ }^{268}$ And these lawyers participated directly in their deceptions, ${ }^{269}$ unlike the prosecutors in Abscam, Parker, and Operation Greylord, who merely supervised undercover operatives and agents. ${ }^{270}$ Nonetheless, the same slippery slope argument that applies to other subject areas of the law can be used to examine federal prosecutors as well. Where is the line to be drawn? Can undercover stings be run by lawyers for the Securities and Exchange Commission or the Department of Homeland Security? ${ }^{271}$ And if so, what about the targets of those civil or quasi-criminal sting operations? May suspects also resort to deception? Or are defense lawyers in actual practice held to a higher ethical standard than prosecutors, notwithstanding all the lofty language to the contrary ${ }^{272}$

Moreover, federal prosecutors today are not the only lawyers who engage in complex, multi-jurisdictional litigation and investigations. Many cases, both private and public, and many law firms cross state borders. The Justice Department Office of Professional Responsibility already employs lawyers who keep current with ethics rules in various jurisdictions and are available to advise field lawyers in the various U.S. Attorneys' offices. And while it may be burdensome and inconvenient for individual prosecutors to learn and comply with local ethics rules, avoiding expense and inconvenience is not necessarily the loftiest goal or sine qua non in conceptualizing and promulgating ethics rules. ${ }^{273}$ In any

also Statement of Deputy Attorney General Eric H. Holder, Jr. before the Sub-Committee on Criminal Justice Oversight, U.S. Senate Judiciary Committee (March 24, 1999), available at http://justice. gov/archive/dag/testimony/dagcrim032499.htm.

267. See generally Zacharias \& Green, supra note 147. And, of course, prosecutors have special obligations under Model Rule 3.8, including disclosure of exculpatory evidence, avoiding subpoenaing privileged materials and refraining from prejudicial public comments. Id. at 212 .

268. See In re Pautler, 47 P.3d 1175, 1176 (Colo. 2002) (en banc); In re Friedman, 392 N.E.2d 1333, 1333 (IIl. 1979); In re Malone, 105 A.D.2d 455, 455 (N.Y. App. Div. 1984).

269. See case descriptions supra Part III.B, C.

270. See case descriptions supra Part IV.A. Malone actually counseled a corrections officer to lie, and Malone himself directly participated in creating a dummy, perjured record, along with a parallel truthful record. Malone, 105 A.D.2d at 456-57.

271. And, as mentioned in Part IV above, Minnesota lawyer-prosecutors themselves resort to undercover investigators in their own investigations of suspended or disbarred lawyers. See Wernz, supra note 176.

272. See, e.g., MODEL RULES $3.8 \mathrm{cmt} \mathrm{[1]} \mathrm{("A} \mathrm{prosecutor} \mathrm{has} \mathrm{the} \mathrm{responsibility} \mathrm{of} \mathrm{a} \mathrm{minister} \mathrm{of}$ justice and not simply that of an advocate."); Zacharias \& Green, supra note 147, at 227 ("[B]oth state and federal prosecutors have been held to a higher standard than other lawyers. They are charged with an overarching duty to seek justice.").

273. The money spent on the Abscam investigation alone was so vast and tempting that the defense claimed that the bribes offered to congressmen and other targets of the investigation violated 
event, the point of this Article is not that we should restrict or shut down federal criminal investigations. Rather, this Article assumes that undercover investigations are here to stay, but posits that the playing field should be leveled.

The law can continue to develop on a case-by-case basis, with individual judges or bar associations deciding intuitively which subject areas of the law justify undercover deception on an ad hoc, "I know it when I see it," basis. But it makes more sense to avoid such value-laden subjective categories, which vary from judge to judge and among different parts of the country. Rather, it is more logical to focus on the conduct of individual attorneys, regardless of their public- or private-sector status, or the subject matter of the client's underlying claim.

\section{The States Should Reconsider Status-Based Exceptions}

It is time to reconsider status-based analysis of undercover investigations. Status-based subject-matter factors are highly subjective, valueladen, and political. It is probably not desirable to treat groups of lawyers differently based on the status of their client as a member of the public sector versus the private sector, or based on the subject matter of the underlying claim or investigation. ${ }^{274}$

Rather, it makes more sense, and is more objective, to focus on the conduct of the attorneys themselves, as well as the investigative techniques which they employ, both directly and indirectly. This avoids a fragmented pecking order of bar sub-disciplines, in which certain conduct is permitted by some lawyers in one part of the country, but not permitted by lawyers doing different work in other parts of the country. The need for a focus on attorney conduct is particularly relevant in light of the growth of multi-jurisdictional practice, sometimes by large national or international firms.

Conversely, it is preferable, from the viewpoint of the organized bar, for practicing lawyers to focus on the fundamental principles of ethical conduct, rather than on the subject matter of their cause or on the status of their client. It is not desirable from the perspective of attorney discipline for some lawyers to think that they have to be especially careful, for instance, in a bankruptcy proceeding, but to think that they can cast

due process. See Blecker, supra note 107; United States v. Myers, 692 F.2d 823 (2d Cir. 1982); United States v. Jannotti, 729 F.2d 213 (3d Cir. 1984). Such expenditures would be sufficient to fund a small army of ethics lawyers.

274. Isbell and Salvi wrote: 'Nor does the nature of the supervising lawyer's client, as between public and private entities, or the fact that in a given instance the objectives of the testers or investigators are socially desirable, provide a basis for distinguishing between misrepresentations that are ethically permissible and those that are not." Isbell \& Salvi, supra note 22, at 829. 
caution to the wind in a civil rights investigation, in which anything goes. The ends do not necessarily justify the means. In fact, the cases are replete with examples of lawyers who were presumably so blinded with righteous zeal that they crossed the line and lied or suborned perjuryfundamental ethical transgressions-in pursuit of important law enforcement objectives. ${ }^{275}$ In this respect, status-based distinctions can have the undesirable effect of emboldening some lawyers to cross the line in their investigative techniques. Pautler, Friedman, and Malone each believed that the justice of their causes justified the use of deception, and each paid a price. Their status as prosecutors may have tended to obscure their own perceptions of their ethical duties as lawyers. Moreover, there are double standards at play, as illustrated by the Abscam and Operation Greylord investigations, in which federal prosecutors obtained valid convictions based on investigative techniques that might have earned reprimands for their state and local counterparts. ${ }^{276}$

Simple and clear fundamental ethical precepts are more likely to be remembered, followed, and enforced than the status-based criteria in the subject-matter axis. Accordingly, this Article recommends that statusbased factors should give way to a more uniform, conduct-based analysis. On the other hand, one might argue that status-based distinctions have the virtue of clarity and that conduct-based analysis, like statusbased distinctions, will have to be undertaken on a case-by-case basis. Eliminating status-based distinctions will not end subjectivity or judgment calls in legal ethics. Whether a particular attorney's conduct was unduly deceptive, or worthy of discipline, will still be decided on a caseby-case basis, depending on the background, judgment, and moral values of an individual judge, ethicist, or disciplinary committee. However, that decision will not depend on the happenstance of the attorney's status or the nature of the client's claim.

And there is hardly bright-line clarity under the existing law. For example, consider the situation in Illinois, where federal prosecutors were permitted, in Operation Greylord, to supervise FBI agents who committed perjury in fabricated cases as part of a sting to prosecute judicial corruption. ${ }^{277}$ A state prosecutor was publicly censured six years earlier in Illinois for similar conduct. ${ }^{278}$ And Daniel Gatti was disciplined for the same sort of conduct that was approved in writing by Ore-

275. See In re Malone, 105 A.D.2d 455, 455 (N.Y. App. Div. 1984); In re Friedman, 392 N.E.2d 1333, 1333 (IIl. 1979).

276. Compare Friedman, 392 N.E.2d 1333 with United States v. Murphy, 768 F.2d 1518 (7th Cir. 1985).

277. Murphy, 768 F.2d at 1528.

278. Friedman, 392 N.E.2d 1333. 
gon state ethics authorities in response to his own complaint against the conduct of law-enforcement agents. ${ }^{279}$ Thus, there is little consistency under existing practice.

The ABA Model Rules of Professional Conduct should be amended, along the lines of the Oregon amendment, to permit the use of limited deception in investigations regardless of status or subject area of the law, provided that the investigation is necessary, the evidence is not available by other means, the attorney's involvement is indirect, and no other ethical rules or laws are broken.

However, as discussed infra in Part VII, the use of covert activity should be limited to deception as to the undercover agent's identity and purpose and should otherwise be compliant with law and the Model Rules. We will now turn to an analysis of the sort of conduct-based factors that have been addressed by the courts and ethicists, and which should inform future consideration of undercover investigations.

\section{AN ANALYSIS OF CONDUCT-BASED FACTORS}

We will now turn to consideration of the various conduct-based factors that the courts and commentators have analyzed in determining the propriety of undercover investigations supervised by attorneys. These include the directness of the attorney's involvement in the deceit, the necessity for deception, the existence of alternative methods for obtaining the same information, and compliance with other legal or ethical rules.

\section{A. The Direct-Indirect Dichotomy}

The Model Rules say that a lawyer may not do through an intermediary that which is directly prohibited. ${ }^{280}$ While the courts and state bars have not always explicitly addressed this factor, their opinions appear to have largely depended, with some notable exceptions, ${ }^{281}$ on whether the attorney acted directly or through an intermediary. Thus, in Pautler and Gatti-two major cases disallowing deception - the attorney directly lied to the would-be client and medical billing company, respectively. ${ }^{282}$ In

279. In re Gatti, 8 P.3d 966 (Or. 2000).

280. MODEL RULES R. 8.4(a).

281. Midwest Motor Sports v. Arctic Cat Sales, Inc., 347 F.3d 693 (8th Cir. 2003).

282. In re Pautler, 47 P.3d 1175 (Colo. 2002) (en banc); Gatti, 8 P.3d 966. It is interesting to speculate as to whether a different result would have been obtained if Mark Pautler had instead instructed a police detective to pose as the suspect's legal aid lawyer. There were so many other problems with the District Attorney's conduct in that case that it is difficult to isolate any one factor. The deception there was broader and deeper than necessary; it resulted in a confession that the government sought to use; it continued on longer than was necessary to obtain the surrender of the sus- 
cases allowing undercover operations, such as Parker, Apple Corps, Abscam, Operation Greylord, and Gidatex, the lawyers, with one exception, ${ }^{283}$ operated through intermediaries. ${ }^{284}$ In fact, the district court in Parker specifically distinguished Gatti (in which the lawyer directly deceived an insurance administrator) because the latter case "does not involve a government attorney's supervision of agents engaged in a formal criminal investigation." 285 Notwithstanding the prohibition of Model Rule 8.4 (a), the courts are just more lenient with attorneys who practice their deception indirectly.

Some states have dealt with the conflict by simply amending their rules to permit indirect supervision of undercover investigations in which deception is used. Florida, as mentioned, permits a government lawyer to supervise an undercover investigation in which the prosecutor does not personally participate. ${ }^{286}$ And Oregon, in amending its rules in the wake of the train wreck left by the Gatti decision, authorized only lawyers' indirect participation in undercover investigations. ${ }^{287}$ The amendment, by its terms, states that it is not unethical for lawyers to "advise clients or others about or to supervise" others in otherwise lawful covert operations. ${ }^{288}$

In In Re Ositis, an Oregon lawyer was reprimanded for deceiving a non-party through an investigator who posed as a journalist. ${ }^{289}$ This conduct took place under the pre-Gatti Oregon Code, which did not contain an exception for undercover investigations. Although the investigator had conceived the ruse, the attorney "suggested a particular line of in-

pect; and it subverted the attorney-client relationship, destroying the suspect's trust in the legal system.

283. In Apple Corps, one of the calls to the stamp company was made by counsel of record using her married name. See Apple Corps Ltd. v. Int'l Collectors Soc'y, 15 F. Supp. 2d 456, 462 (D.N.J. 1998).

284. On the other hand, in Midwest Motor Sports, the court disallowed evidence obtained by the attorney's investigator in violation of the no contact rule. See Midwest Motor Sports, 347 F.3d at $697-700$.

285. See United States v. Parker, 165 F. Supp. 2d 431, 478 (W.D.N.Y. 2001) (emphasis added). On the other hand, an Oregon case decided prior to the 2002 amendment of its ethics code resulted in discipline of a private lawyer in a civil dispute who did not directly participate in an investigation, but merely instructed an investigator to use deception. In re Ositis, 40 P.3d 500 (Or. 2002). The Oregon State Bar opined that Ositis would be decided differently under the new rules.

286. FlA. RULES OF PROF'L CONDUCT R. 4-8.4(c).

287. See OR. RULES OF PROF'L CONDUCT R. 8.4, discussed supra Part III.E.

288. The Oregon State Bar Association has interpreted the revised Rule 8.4(b) to permit supervision in which the lawyer does not "participate directly" in the covert activity. Or. Ethics Op., supra note 135 .

289. In re Ositis, 40 P.3d 500 (Or. 2002). Ositis was decided under Oregon's pre-Gatti Code. It would have been decided differently under the post-Gatti revisions to the Oregon Code. See Or. Ethics Op., supra note 135, at 4 ("it appears that the lawyer's involvement with the trick interview as an advisor and not as a direct participant would be permissible under Oregon RPC 8.4 (b)."). 
quiry," "attached his own set of directions," and "exercised direction and control" over the investigator. Thus, the lawyer's close supervision of the investigator's ruse earned him a reprimand under the pre-Gatti Code." 290

The Oregon State Bar Association revisited Ositis in 2005, under the post-Gatti revisions to the Oregon ethics code. ${ }^{291}$ According to the Oregon State Bar, the revised rule, permitting supervision of undercover investigations, would permit Ositis' role in the investigator's deception. ${ }^{292}$ Conversely, a hypothetical authored by the Oregon State Bar suggests that Daniel Gatti's own conduct, in posing as a chiropractor, would still be unethical under the revised rules because he participated directly in the deception. ${ }^{293}$

While Oregon has reached a coherent and logical solution to the problem of deception, its rationale is harder to explain. Intuitively, it somehow seems worse for a lawyer to engage in deception directly than to condone its use by others. The Oregon State Bar has explained that "[t] he safe harbors of Oregon RPC 8.4(b) preserve the fundamental tenet of the basic truthfulness of the words spoken by a lawyer."294 The Oregon Bar seems to be suggesting that it just seems undignified or wrong for lawyers to get their hands dirty, or to engage directly in deception. Is a wink and a nod somehow ethically different from an outright lie? Would Ositis have escaped reprimand, even under the old Oregon code, had he simply told his investigator to "do what you gotta do," instead of involving himself in, and ratifying, the details of the deception?

The Article concludes that the directness of attorney participation in the subterfuge is and should continue to be an important factor under the conduct-based axis.

\section{B. How Significant is the Deception?}

An appropriate factor in analyzing the conduct axis is the significance of the deception, as well as any resulting damage. The intellectual property decisions generally have considered minimally-intrusive sting operations, in which the investigator walks into a public retail space and, from a low level clerk, purchases merchandise that is being sold to the

290. Compare Ositis, 40 P.3d. at 375 with United States v. Hammad, 858 F.2d 834 (2d Cir. 1988), in which an informant became the "alter ego" of the government because a prosecutor furnished him with a fabricated subpoena in an effort to elicit incriminating information from the suspect.

291. Or. Ethics Op., supra note 135, at 4.

292. Id.

293. Id.

294. Id. 
buying public anyway. The clerk is merely selling the investigator the same merchandise that was being sold to other customers before and after the transaction. Thus, the deception is mild or in some cases nonexistent, and is limited to identity and purpose. Also, in most intellectual property cases, the deception causes no harm to its subject, aside from permitting the gathering of evidence. By the same token, Daniel Gatti merely misrepresented his identity and purpose in telephoning the medical review company. ${ }^{295}$ A different result obtains when, as in Midwest Motor Sports, the investigator has a substantive discussion with a highranking officer in the control group of a represented party, ${ }^{296}$ or when, as in Pautler, the prosecutor's deception undermines the suspect's confidence in the attorney-client relationship. ${ }^{297}$

In its opinion on undercover investigations, the New York County Lawyers Association opined that "dissemblance" is permissible and is distinguishable from "dishonesty, fraud, misrepresentation and deceit."298 The ethically permitted "dissemblance" "is limited to identity and purpose and involves otherwise lawful activity undertaken solely for the purpose of gathering evidence."299 Thus, the New York County opinion suggests that only a limited amount of trickery or deception is permissible and that discrimination testers, at least in civil cases, should be kept on a short leash by their supervising attorneys.

In contrast, the deception practiced in Pautler tended to undermine the constitutional right to counsel and the attorney-client relationship in ways that clearly disturbed the Colorado Supreme Court. ${ }^{300}$ The district attorney could have simply kept his deception to a minimum, by saying, for example, "I am your attorney, and you should surrender, but do not say anything to me or anyone else about the case." Pautler could have revealed his true identity the moment the handcuffs were secured on Neal's wrists. The court in Pautler noted that the assistant district attorney did not act promptly to disabuse his deceived "client" after securing

295. In re Gatti, 8 P.3d 966 (Or. 2000).

296. Midwest Motor Sports v. Arctic Cat Sales, Inc., 347 F.3d 693 (8th Cir. 2003) (investigator interviewed adverse party in franchise dispute).

297. In re Pautler, 47 P.3d 1175, 1180 (Colo. 2002) (en banc).

298. N.Y. County Ethics Op. 737, supra note 193, at 2.

299. Id. at 1 .

300. The criticism of Pautler's deception on Sixth Amendment grounds is analyzed by Rebecca Cross in her article. Cross, supra note 62, at 223, 230. While some critics claim that Pautler's deception violated the client's trust in his attorney, Cross argues that the suspect's constitutional rights did not attach until he was in custody. Id. at 230. 
his surrender. ${ }^{301}$ Thus, on the conduct axis, Pautler's deception was broader than necessary.

\section{How Necessary Is the Deception?}

Necessity is an element considered explicitly or implicitly in every treatment of deception. The classic example, as mentioned above, is the housing discrimination tester. A landlord or employer is very unlikely to respond truthfully to a direct inquiry from a disclosed civil rights investigator. In criminal investigations, terrorist and organized-crime groups take elaborate measures to avoid detection. These criminal enterprises cannot be penetrated and prosecuted without the use of deception.

On the other hand, deception is rarely necessary in formal litigation, since court-supervised discovery is the primary method of developing evidence for use at trial. It is difficult to imagine a judge who would appreciate a resort to deception in order to circumvent a discovery order. Thus, in Midwest Motor Sports, the court noted that the unauthorized contact with the represented adverse party took place while discovery was underway. ${ }^{302}$ And the lawyer in In re Wood improperly hired an investigator to obtain confidential client materials which "could have been subpoenaed.,"303 Accordingly, necessity is an important factor on the conduct axis. Gratuitous or unnecessary deception is unlikely to pass muster, particularly when the same information would have been available without resort to trickery.

\section{Is the Deception Otherwise Illegal or Unethical?}

Of course, deception, even where ethically justified, cannot be analyzed in a vacuum. Rather, attorney conduct must be considered in the overall context of the other ethical rules. Eliminating status-based rules does not otherwise transform or supersede the remainder of the Model Rules. Undercover investigations are not acceptable when used to circumvent the no-contact rule, ${ }^{304}$ or to elicit privileged material. Lawyer lying is still proscribed by ABA Model Rule 4.1, and, under some narrow circumstances, a lawyer even may be disciplined under that rule for

301. Indeed, the court explicitly condemned the unnecessary continuation of Pautler's deception after the arrest: "After the immediacy of the events waned, Pautler should have taken steps to correct the blatant deception in which he took part." Pautler, 47 P.3d at 1184.

302. Midwest Motor Sports v. Arctic Cat Sales, Inc., 347 F.3d 693 (8th Cir. 2003).

303. In re Wood, 526 N.W.2d 513, 514 (Wisc. 2005).

304. MODEL RULES. R. 4.2 (2008). 
standing by mutely when an adverse party labors under a misconception. $^{305}$

The use of deception by an investigator is not acceptable when used to circumvent standing discovery orders or procedures. ${ }^{306}$ As we have seen, some but not all, authorities have posited that the deception may not rise to the level of fraud on the court, or perjury. ${ }^{307}$

Additional issues were raised by the Hewlett-Packard corporate scandal, in which investigators retained by corporate in-house counsel investigated leaks from a member of the corporate board to journalists. ${ }^{308}$ Using false identities, these investigators obtained confidential telephone records of board members, journalists, and their families. ${ }^{309}$

To prevent future abuse of confidentiality, Congress passed the Telephone Records and Privacy Protection Act of 2006, to supplement existing prohibitions in the Gramm-Leach-Bliley Act and other consumer privacy-protection statues. ${ }^{310}$ There are also state privacy laws to consider. $^{311}$ Lawyers must make reasonable efforts to ensure that the investigators they employ do not run afoul of these laws, and should not exploit, use, or ratify evidence obtained illegally. ${ }^{312}$

\section{E. "Violations of Law"}

As noted, the revisions to Oregon Rule of Professional Conduct 8.4 permit lawyers to supervise undercover investigators "in the investigation of violations of civil or criminal law or constitutional rights," subject to the remaining provisions of the Rules. ${ }^{313}$ Covert investigations may be

305. See Barry R. Temkin, Misrepresentation by Omission in Settlement Negotiations: Should There Be a Silent, Safe Harbor?, 18 GEo. J. LEGAL ETHICS 179, 201 (example of plaintiff's lawyer who fails to disclose death of client during settlement negotiations).

306. Wood, 526 N.W.2d 513.

307. In re Friedman, 392 N.E.2d 1333 (Ill. 1979); In re Malone, 105 A.D.2d 455 (N.Y. App. Div. 1984). On the other hand, many federal investigations, particularly prosecutions of judicial corruption, involve manufactured crimes. See discussion of Operation Greylord, supra note 107; United States v. Murphy, 768 F.2d 1518 (7th Cir. 1985).

308. Stewart, supra note 5, at 159-60.

309. Id.

310. See Rohde, supra note 18; Arenz, supra note 3; Gramm-Leach-Bliley Act, Pub. L. No. 106-102, 113 Stat. 1338 (1999) (codified as amended in scattered sections of 12 and 15 U.S.C.).

311. See Rohde, supra note 18; Arenz, supra note 3.

312. See MODEL RULES R. 8.4(b) (2008) (stating that a lawyer may not commit a criminal act that reflects adversely on the lawyer's honesty, trustworthiness, or fitness as a lawyer in other respects); MODEL RULES R. 5.3 (2008) (stating that a lawyer must supervise non-lawyer subordinates and may not ratify unethical conduct). But see Stagg v. New York City Health \& Hospitals Corp., 556 N.Y.S.2d 779, 780 (N.Y. App. Div. 1990) (stating that a lawyer may introduce evidence obtained by investigator without lawyer's knowledge, even if obtained unethically, which it wasn't).

313. OR. RULES OF PROF'L CONDUCT R. 8.4(b). 
to the remaining provisions of the Rules. ${ }^{313}$ Covert investigations may be ethically employed only when there is evidence of "unlawful activity." It is not entirely clear what is meant by these phrases, which are considered interchangeable by the Oregon State Bar. ${ }^{315}$ Oregon Formal Opinion 2005-173 attempted to define these phrases by use of a hypothetical example in which the lawyer's client is injured in a fall and is denied worker's compensation benefits. ${ }^{316}$ The lawyer advises the client to send an acquaintance, under a false pretense, to interview a purported witness to the accident. This, according to the Oregon Bar, would be impermissible because there is no underlying claim of "unlawful activity" or violation of civil or criminal law. ${ }^{317}$ Unlawful activity would require a violation of a statutory or common-law duty, which is not the case where there is, essentially, a no-fault standard for collecting workers' compensation benefits. ${ }^{318}$

In another hypothetical, the Oregon Bar considered the case of an assistant district attorney approached by police officers who report suspicious "foot traffic" at a residence. ${ }^{319}$ This leads them to believe that drugs are being sold at that house. ${ }^{320}$ Because there is "a reasonable possibility that unlawful activity has taken place, is taking place, or will take place in the foreseeable future, ${ }^{, 321}$ the prosecutor may ethically authorize the police to send an undercover agent posing as a drug buyer to the address.

It is not entirely clear what is accomplished by limiting the exception to situations in which the lawyer reasonably believes that "unlawful activity" is taking place. ${ }^{322}$ The practical effect of this clause is to permit undercover investigations by lawyers wielding affirmative claims, but to deny it to lawyers defending against the same claims. Thus, in the Oregon Bar's own example, a district attorney may use a covert operation to

313. OR. RULES OF PROF'L CONDUCT R. 8.4(b).

314. Id.

315. Or. Ethics Op., supra note 135.

316. Id.

317. The New York County Lawyers' Association, in Ethics Opinion 737, similarly limits the scope of its exception to violations of law in specified subject-matter areas. See N.Y. County Ethics Op. 737, supra note 193.

318. Or. Ethics Op., supra note 135, at 4.

319. Id. at 1 .

320. Id. at 1, 6-7.

321. Id. at 2 (quoting OR. RULES OF PROF'L CONDUCT R. 8.4(b)).

322. Compare OR. Rules OF PROF'L CONDUCT R. 8.4(b) with N.Y. County Ethics Op. 737, supra note 193 (stating that dissemblance is limited to "violation of civil rights or intellectual property rights and the lawyer believes in good faith that such violation is taking place or will take place imminently or (b) the dissemblance is expressly authorized by law"). 
investigate allegations of drug dealing. ${ }^{323}$ But the defense attorney in the same case may not resort to such techniques unless there is reason to suspect unlawful activity, such as witness tampering or grand jury perjury. ${ }^{324}$ Simply locating an exculpatory witness would not justify deception. By logical extension, the plaintiff's lawyer in a trademark or civil rights case may use deceit, but the defense attorneys, who are merely defending against the allegations of a violation of law in the same case, may not. Also, consider the example of the plaintiff's lawyer in an ordinary tort case based on negligence, who may use deception to investigate the defendant's unlawful conduct. However, the defendant in the same case may not resort to such techniques absent a reasonable belief that there is unlawful activity-such as perjury or insurance fraud-taking place. ${ }^{325}$

Most troublesome of all is the imbalance between the resources available to the government and the defense in criminal cases, as discussed above. ${ }^{326}$ The government may ethically go undercover to arrest a drug dealer for selling an ounce of marijuana. But the defense may not use covert deception to locate a recalcitrant exculpatory witness in a death penalty case, absent evidence of unlawful conduct. Under this formulation, the defense would be allowed to dissemble in order to investigate a claim that a government witness committed perjury, obstructed justice, or otherwise engaged in unlawful conduct. Moreover, if a defense witness becomes unavailable due to witness tampering or other unlawful conduct, the Oregon rule would permit resort to a covert investigation. Nonetheless, if a witness is unavailable due to simple fear, recalcitrance, or hostility to the defense, the Oregon formulation would not explicitly permit deception by the defense. ${ }^{327}$

In short, the Oregon formulation, while admirably dispensing with status-based distinctions, probably does not go far enough. For a variety of reasons, discussed above, the requirement that there be illegal activity

323. Or. Ethics Op., supra note 135, at 4 (prosecutor could ethically supervise police officers in an undercover drug buy operation based upon probable cause to believe that illegal drug activity was underway).

324. Id.

325. See, e.g., Stagg v. New York City Health \& Hospitals Corp., 556 N.Y.S.2d 779 (N.Y. App. Div. 1990). In Stagg, an insurance investigator posed as a potential buyer for the injured plaintiff's truck, and, in the course of doing so, observed the plaintiff doing things he had swore he could not do, such as run a business. This investigation was not authorized by the defense attorney, and, even if it had been so authorized, would not have run afoul of the deception or no-contact rules. Id. at 780 .

326. See discussion supra Part VI.

327. As mentioned supra, a special master in Wisconsin has found no ethics violation by a criminal defense attorney whose investigator used a ruse to trick a teenager into surrendering his computer, which was laden with pornography. See Supreme Court referee, supra note 8. 
as a predicate to permitting supervision of undercover investigations gives an advantage to the prosecution in criminal cases and to the claimant in civil cases. The ethical rules should be a reciprocal two-way street, by permitting undercover investigations without regard to the nature of the underlying claim or defense.

\section{CONCLUSION}

The ABA Model Rules of Professional Conduct proscribe conduct involving dishonesty, misrepresentation, or deception. ${ }^{328}$ They also bar an attorney from doing indirectly, through a proxy, that which is ethically prohibited. ${ }^{329}$ Yet, lawyers have supervised and directed investigators for decades in undercover operations aimed at uncovering racial discrimination, political corruption, and organized crime. More recently, some courts and commentators have endorsed attorney involvement in undercover investigations to prosecute intellectual property claims. ${ }^{330}$ Attorney-supervised undercover operations are unlikely to disappear any time soon.

This Article has analyzed the use of deception in investigations along two axes: status-based and conduct-based. The status-based axis considers the type of case and the status of the lawyer supervising the investigation (e.g., a government lawyer supervising a criminal investigation). The conduct-based axis considers the actual conduct of the attorney: Was the deception necessary, was it direct or indirect, did it cause unnecessary harm? Some courts and commentators have argued that no deception should ever be permitted by attorneys, whether they act directly or indirectly. However, the recent trend has been to permit lawyers to supervise, and thereby indirectly participate in, undercover investigations in three substantive areas of the law: criminal, civil rights, and intellectual property. Many jurisdictions permit undercover criminal investigations by government attorneys, but are silent about the rights of defense counsel to use deception.

This Article has argued that status-based distinctions are no longer useful because they are highly subjective and provide little guidance to practicing attorneys, courts, or bar associations. Why should law enforcement attorneys, who theoretically are held to a higher ethical standard than private practitioners, be permitted ethically to supervise undercover operations when the same techniques are ethically off-limits for defense attorneys? Furthermore, there is no reason why intellectual

328. MODEL RULES R. 8.4(c) (2008).

329. MODEL RULES R. 8.4(a).

330. See discussion supra Part IV.C. 
property lawyers should ethically be able to supervise investigations that real property lawyers may not.

In addition, using a status-based approach to ethics actually could lead to unethical conduct by promoting a false sense of ethical immunity among prosecutors and other status-based practitioners. Status-based ethical immunity can lead to arrogance, or at least faulty judgment, by lawyers who have convinced themselves that the ends justify the means. That could be one of the lessons of Friedman, Malone and Pautler, all of which involved prosecutors who were disciplined for using deception in support of laudable goals in subject-matter areas in which some deception traditionally has been tolerated.

Thus, status-based distinctions no longer make sense and should be reconsidered. The effect of the recent rule amendments in Oregon, promulgated in the wake of In re Gatti, has been to eliminate such distinctions. Attorneys in all areas of the law should be judged by the same ethical standards, based on the lawyers' actual conduct as opposed to the status of their clients. Status-based hierarchies should give way to conduct-based rules. Lawyers' conduct should be guided by a number of conduct-based factors, such as: (a) the directness of the lawyer's involvement in the undercover subterfuge; (b) the significance and depth of the deception; (c) the necessity of the deception; (d) the existence of alternative means to uncover the sought-after evidence; and (e) whether the conduct violates other rules and principles, such as the no-contact rule of ABA Model Rule 4.2. The ABA Model Rules should be amended to permit undercover investigations, regardless of the status of the supervising attorney, provided that the investigation is necessary, the evidence is not available by other means, the attorney's involvement is indirect, and no other ethical rules or laws are broken.

By focusing on attorney conduct rather than client status, the debate can return to awareness of and standards for attorney ethics for the entire bar. Such a debate, to be sure, will not eliminate subjectivity and judgment calls. Nonetheless, shifting the analysis to attorney conduct is preferable to an endless, politically-charged debate about which clients' rights are sufficiently important to justify trickery and deception by their lawyers. 